Published in final edited form as:

Methods Enzymol. 2009 ; 462: 45-76. doi:10.1016/S0076-6879(09)62003-6.

\title{
Replacement of $Y_{730}$ and $Y_{731}$ in the a2 Subunit of Escherichia coli Ribonucleotide Reductase with 3-Aminotyrosine using an Evolved Suppressor tRNA/tRNA-Synthetase Pair
}

\author{
Mohammad R. Seyedsayamdost ${ }^{\star}$ and JoAnne Stubbe ${ }^{\star}, \dagger$ \\ *Department of Chemistry, Massachusetts Institute of Technology, Cambridge, Massachusetts, \\ USA \\ †Department of Biology, Massachusetts Institute of Technology, Cambridge, Massachusetts, USA
}

\section{Abstract}

Since the discovery of the essential tyrosyl radical (Y•) in E. coli ribonucleotide reductase (RNR), a number of enzymes involved in primary metabolism have been found that use transient or stable tyrosyl (Y) or tryptophanyl (W) radicals in catalysis. These enzymes engage in a myriad of charge transfer reactions that occur with exquisite control and specificity. The unavailability of natural amino acids that can perturb the reduction potential and/or protonation states of redox-active $\mathrm{Y}$ or $\mathrm{W}$ residues has limited the usefulness of site-directed mutagenesis methods to probe the attendant mechanism of charge transport at these residues. However, recent technologies designed to sitespecifically incorporate unnatural amino acids into proteins have now made viable the study of these mechanisms. The class Ia RNR from E. coli serves as a paradigm for enzymes that use amino acid radicals in catalysis. It catalyzes the conversion of nucleotides to deoxynucleotides and utilizes both stable and transient protein radicals. This reaction requires radical transfer from a stable tyrosyl radical $\left(\mathrm{Y}_{122^{\circ}}\right)$ in the $\beta$ subunit to an active-site cysteine $\left(\mathrm{C}_{439}\right)$ in the $\alpha$ subunit, where nucleotide reduction occurs. The distance between the sites is proposed to be $>35 \AA$. A pathway between these sites has been proposed in which transient aromatic amino acid radicals mediate radical transport. To examine the pathway for radical propagation as well as requirements for coupled electron and proton transfers, a suppressor tRNA/aminoacyl-tRNA synthetase (RS) pair has been evolved that allows for site-specific incorporation of 3-aminotyrosine $\left(\mathrm{NH}_{2} \mathrm{Y}\right)$. $\mathrm{NH}_{2} \mathrm{Y}$ was chosen because it is structurally similar to $\mathrm{Y}$ with a similar phenolic $\mathrm{p} K_{\mathrm{a}}$. However, at $\mathrm{pH} 7$, it is more easily oxidized than $\mathrm{Y}$ by $190 \mathrm{mV}(\approx 4.4 \mathrm{kcal} / \mathrm{mol})$, thus allowing it to act as a radical trap. Here we present the detailed procedures involved in evolving an $\mathrm{NH}_{2} \mathrm{Y}$-specific $\mathrm{RS}$, assessing its efficiency in $\mathrm{NH}_{2} \mathrm{Y}$ insertion, generating $\mathrm{RNR}$ mutants with $\mathrm{NH}_{2} \mathrm{Y}$ at selected sites, and determining the spectroscopic properties of $\mathrm{NH}_{2} \mathrm{Y} \bullet$ and the kinetics of its formation.

\section{Introduction}

Long-range electron transfer (ET) reactions are prevalent in biology, notably in photosynthesis and respiration, and in almost all cases occur between metal cofactors that are spaced 10 to $15 \AA$ apart (Gray and Winkler, 1996; Marcus and Sutin, 1985; Moser et al., 1992; Page et al., 1999, 2003). ET theory, articulated by Marcus, has been immensely useful in dissecting the kinetics and thermodynamics of these reactions. More recently, however, the role of amino acid radicals as mediators of charge transport has been recognized (Cukier 
and Nocera, 1998; Reece et al., 2006). Oxidation of amino acids at neutral $\mathrm{pH}$ requires loss of an electron and a proton, implicating proton-coupled electron transfer (PCET).

Ribonucleotide reductases (RNRs), the topic of this chapter, serve as a paradigm for longrange PCET reactions, in which transient amino acid radicals are involved (Jordan and Reichard, 1998; Stubbe and Riggs-Gelasco, 1998; Stubbe and van der Donk, 1998; Stubbe et al., 2003).

The $E$. coli RNR consists of two homodimeric protein subunits: $\alpha 2$ and $\beta 2$. The $\beta 2$ subunit contains a stable diferric tyrosyl radical $\left(\mathrm{Y}_{122^{\circ}}\right)$ cofactor, which is essential for catalysis and is buried deeply within the protein (Ehrenberg and Reichard, 1972; Nordlund et al., 1990; Reichard and Ehrenberg, 1983; Sjoberg et al., 1978). The $a 2$ subunit harbors the active site, where a cysteinyl radical $\left(\mathrm{C}_{439^{\circ}}\right)$, generated by $\mathrm{Y}_{122^{\bullet}}$ on radical transfer from $\beta 2$, initiates nucleotide reduction (Stubbe, 1990, 1998; Uhlin and Eklund, 1994). This intersubunit radical transfer reaction has been proposed to span a distance of $>35 \AA$ on the basis of the Eklund docking model created from the structures of $\alpha 2$ and of $\beta 2$ (Eklund et al., 2001; Uhlin and Eklund, 1994). A pathway of amino acids that gap the distance between the $\mathrm{Y}_{122^{\circ}}$ in $\beta 2$ and $\mathrm{C}_{439^{\bullet}}$ in $\alpha 2$ has been proposed (Fig. 3.1) (Nordlund et al., 1990; Stubbe et al., 2003; Uhlin and Eklund, 1994). Several properties of the proposed radical transfer pathway in the $E$. coli class Ia RNR have made it difficult to examine with conventional methods. First, replacement of any residue involved in radical propagation by another natural amino acid via site-directed mutagenesis renders the enzyme inactive, thus precluding mechanistic studies (Climent et al., 1992; Ekberg et al., 1996; Stubbe et al., 2003). Second, pre-steadystate kinetic experiments have revealed that radical transfer is preceded by a slow conformational change (Ge et al., 2003). Consequently, to study this process, the ratelimiting step must be changed from the physical step to the radical transfer step. Finally, the system has evolved to avoid buildup of any intermediates during this process, which could result in loss of the essential radical (Licht and Stubbe, 1999). In E. coli RNR, the $\mathrm{Y}_{122^{\bullet}}$ has a lifetime of several days (Atkin et al., 1973).

Site-specific replacement of the tyrosines within the radical transfer pathway (Fig. 3.1) with appropriately designed unnatural amino acids could potentially allow for investigation of the length of the pathway and the existence of transient radical intermediates. Therefore, we have sought modified tyrosines that can block radical transfer because of their inability to be oxidized to the corresponding radical form, report on radical transfer because of their ease of oxidation relative to tyrosine, or change the rate-limiting step from the conformational change to radical transfer by modulating the radical reduction potential over several hundred $\mathrm{mV}$ relative to tyrosine in the physiological $\mathrm{pH}$ range.

To incorporate a thermodynamic block into the radical transfer pathway, we previously chose 3-nitrotyrosine $\left(\mathrm{NO}_{2} \mathrm{Y}\right)$ as an analogue because it is substantially more difficult to oxidize than Y (by $200 \mathrm{mV}$ at pH 7) (Yee et al., 2003b). This block in the pathway could potentially allow accumulation of radical intermediates preceding the site of incorporation. $\mathrm{NO}_{2} \mathrm{Y}$ also functioned as a reporter on the ability of the protein environment to perturb the phenolic $\mathrm{p} K_{\mathrm{a}}$, essential in understanding PCET mechanisms. To insert a radical trap into the pathway, we chose 3,4-dihydroxyphenylalanine (DOPA) because it is substantially easier to oxidize than Y (by $270 \mathrm{mV}$ at pH 7) (Seyedsayamdost and Stubbe, 2006). This 
thermodynamic trap then served as a readout for the involvement of residue 356 in radical transfer. Finally, we chose a series of fluorotyrosine analogues $\left(F_{n} Y s, n=1-4\right)$ which perturb the phenolic $\mathrm{p} K_{\mathrm{a}}$ and modulate the radical reduction potential relative to $\mathrm{Y}$ by -40 to $+270 \mathrm{mV}$, depending on the reaction $\mathrm{pH}$ and the number of fluorines (Seyedsayamdost $e t$ al., 2006a). These analogues allowed us to change the rate-limiting step in RNR and to uncouple the electron and proton flows at a given residue (Seyedsayamdost et al., 2006b; Yee et al., 2003a). We recently reported detailed procedures for replacement of $Y_{356}$ in $\beta 2$ by expressed protein ligation (EPL) methods (Muralidharan and Muir, 2006; Pellois and Muir, 2006) to site-specifically insert $\mathrm{NO}_{2} \mathrm{Y}, \mathrm{DOPA}$, and $\mathrm{F}_{\mathrm{n}} \mathrm{Ys}$ (Seyedsayamdost et al., 2007c).

To study residues involved in radical transfer in $a 2$ in a similar fashion, we have considered two methods for the insertion of unnatural amino acids. The first method, semisynthesis of the $a$ subunit of RNR using EPL, is not feasible because of the large size of $\alpha 2$ (each monomer is 761 amino acids), its poor solubility, and the position of the residues to be replaced ( $\mathrm{Y}_{730} / \mathrm{Y}_{731}$, Fig. 3.1). We have therefore employed an alternative method for sitespecific insertion of unnatural amino acids. Herein, we detail our approach for inserting the unnatural tyrosine analogue 3-aminotyrosine $\left(\mathrm{NH}_{2} \mathrm{Y}\right)$ into the $a 2$ subunit of RNR using suppressor tRNA/aminoacyl-tRNA synthetase (RS) methodologies (Seyedsayamdost et al., 2007b; Wang and Schultz, 2004; Xie and Schultz, 2005).

\section{Site-Specific Insertion of Unnatural Amino Acids using the Suppressor tRNA/RS Method}

Schultz and colleagues have developed robust methods for site-specific incorporation of a wide range of unnatural tyrosine and phenylalanine analogues, in vivo (Wang and Schultz, 2004; Xie and Schultz, 2005, 2006). In collaboration with the Schultz lab, we have been able to apply this methodology to incorporate $\mathrm{NH}_{2} \mathrm{Y}$ into $a$ (Seyedsayamdost et al., 2007a,b). In this method, six residues at or near the active site of the Methanococcus jannaschii Tyr-RS were randomized to generate a library of RSs. The resulting library was then subjected to a set of positive and negative selections (see section 4) to find one or several RSs that can selectively charge the cognate $M$. jannaschii $\mathrm{RNA}_{\text {Tyr }}$ with $\mathrm{NH}_{2} \mathrm{Y}$ and not with $\mathrm{Y}$. This suppressor tRNA, designated mutRNA $\mathrm{CUA}_{\mathrm{A}}$, contains an amber stop codon and was optimized for interacting with the library of RSs (Wang and Schultz, 2001). A number of criteria must be satisfied by the selected $M$. jannaschii mutRNA ${ }_{\mathrm{CUA}} / \mathrm{RS}$ pair to make it suitable in this procedure (Xie and Schultz, 2005). First, the mutRNA $\mathrm{CUA}_{\mathrm{A}} / \mathrm{RS}$ pair must be orthogonal to the expression host's tRNA/RS pairs; that is, the amber suppressor mutRNA $_{\text {CUA }}$ must not be charged by any RSs from the host organism in vivo. Second, the selected RS must charge only its cognate mutRNA ${ }_{\text {CUA }}$ and not any of the host's tRNAs. Third, in vivo RSs must not be able to charge their cognate tRNAs with the unnatural amino acid. Fourth, the unnatural amino acid must be taken up by the host cell and must not be toxic. Finally, the gene of interest, with the amber stop codon at the residue where the unnatural amino acid is to be inserted, must be expressed inside the host. If all of these criteria are met, then the gene of interest and the genes for the evolved mutRNA $\mathrm{CUA}_{\mathrm{A}} / \mathrm{RS}$ pair specific for the unnatural amino acid are transformed into the host, and the expression of the 
protein of interest results in the incorporation of the unnatural amino acid with high fidelity and specificity.

Both the expressed protein ligation method (Dawson and Kent, 2000; Giriat and Muir, 2003; Mootz et al., 2003; Muir, 2003; Perler, 2005) and the suppressor tRNA/RS method (Wang and Schultz, 2004; Wang et al., 2006; Zhang et al., 2003) have been used in vitro and in vivo, each with its advantages and disadvantages. While we have used EPL extensively with the $\beta$ subunit and gained important insights into radical transfer, the tRNA/RS method promises to be more robust for incorporation of unnatural amino acids into both RNR subunits for several reasons. First, it allows incorporation of the unnatural amino acid anywhere in the protein, not just at the $\mathrm{C}$ - or $\mathrm{N}$-terminus. Muir and colleagues have developed methods for insertion of probes in the middle of proteins (Cotton et al., 1999); however, refolding of $\alpha$ or $\beta$ is not an option, and therefore incorporation of unnatural amino acids by these techniques into the center of the protein would not be viable. Second, the $\beta$ subunit of RNR is a dimer. Therefore, the semisynthesis of $\beta 2$ by EPL required separation of the full-length dimeric $\beta 2$, the heterdimeric $\beta \beta$ (composed of a full-length monomer, $\beta$, and a truncated monomer, $\beta$ ) and the doubly truncated dimer $\beta 2$. While this separation was possible, it came at the expense of protein yield. Third, expressed protein ligation of $\beta 2$ required two additional mutations to provide sufficient quantities of semisynthetic $\beta 2$ for physical biochemical methods necessary to study radical transfer in RNR. A serine residue $\left(\mathrm{S}_{354}\right)$ needed to be changed to a cysteine for the ligation reaction, and the residue at the site of the activated thioester-intein construct $\left(\mathrm{V}_{353}\right)$ needed to be replaced with a less bulky amino acid (Gly) to increase the yield of the ligated product (Yee et al., 2003b). With the tRNA/RS method, insertions can be made with a single unnatural point mutation. In addition, the requirement to assemble the essential diferric $\mathrm{Y}_{122^{\bullet}}$ cofactor of $\beta 2$ and the sensitivity of the unnatural amino acids to oxidation made the intein method challenging at every step.

As with every method, there are a number of problems that may be encountered with the suppressor tRNA/RS method. The unnatural amino acid of interest might not be readily taken up into the host cell or may be toxic. In addition, each unnatural amino acid requires evolution of a new RS. As documented subsequently, the suppressor tRNA/RS pair has been highly successful in site-specific insertion of $\mathrm{NH}_{2} \mathrm{Y}$ into RNR and has allowed us to perform mechanistic studies, which would not have been accessible by other methods.

\section{3. $\mathrm{NH}_{2} \mathrm{Y}$, a $\mathrm{Y}$ Analogue for Investigating Enzymatic PCET Reactions}

\subsection{Overview: Choice of $\mathrm{NH}_{2} \mathrm{Y}$}

$\mathrm{NH}_{2} \mathrm{Y}$ was chosen as a probe because its radical reduction potential of $0.64 \mathrm{~V}(\mathrm{pH} 7.0)$ is $0.19 \mathrm{~V}$ lower than that of Y (DeFelippis et al., 1991), which suggests that it might act as a radical trap and directly report on the participation of residues $Y_{730}$ and $Y_{731}$ in radical transfer (Fig. 3.1). In addition, the ease of synthesis of $\mathrm{NH}_{2} \mathrm{Y}$ (Seagle and Cowgill, 1976) and its kinetic stability to oxidation relative to other low reduction potential radical traps, such as DOPA (Jovanovic, 1994), make it a more practical target. The characterization of the UV-vis and EPR spectroscopic properties of the oxidized $\mathrm{NH}_{2} \mathrm{Y}$, the amino tyrosyl radical $\left(\mathrm{NH}_{2} \mathrm{Y} \bullet\right)$, will allow $\mathrm{NH}_{2} \mathrm{Y}$ to serve as a probe for enzymes that are thought to 
employ transient $\mathrm{Y} \bullet \mathrm{s}$, or modified $\mathrm{Y} \bullet \mathrm{s}$ in catalysis or in electron transfer (Seyedsayamdost $e t$ al., 2007b). The ability to incorporate $\mathrm{NH}_{2} \mathrm{Y}$ may also be of more general use for sitespecific appendage of probes, as recent studies have shown that $\mathrm{NH}_{2} \mathrm{Y}$ itself can be derivatized with fluorescent dyes (Hooker et al., 2004; Kovacs et al., 2007). Further, we have shown that $\mathrm{NH}_{2} \mathrm{Y}$ can be used as a redox-active distance probe to determine molecular distances of 15 to $80 \AA$ between two paramagnetic sites within an enzyme or enzyme complex (Bennati et al., 2003; Seyedsayamdost et al., 2007a).

Before performing directed-evolution on the library of RSs to select for an $\mathrm{NH}_{2} \mathrm{Y}-\mathrm{RS}$, three criteria must be fulfilled by $\mathrm{NH}_{2} \mathrm{Y}$ : it must be taken up by $E$. coli cells, it must not be toxic, and it must not be incorporated into proteins by any endogenous RSs. In this section, we outline the procedures used to determine the uptake and toxicity of $\mathrm{NH}_{2} \mathrm{Y}$.

\subsection{Protocol for assessing uptake and toxicity of $\mathrm{NH}_{2} \mathrm{Y}$ in $\mathrm{E}$. coli}

To assess the uptake of $\mathrm{NH}_{2} \mathrm{Y}$ by E. coli (Xie and Schultz, 2005), growth of DH10B cells (Invitrogen) was initiated in the absence of antibiotics in two 50-mL Erlenmeyer flasks containing $15 \mathrm{~mL}$ of glycerol minimal media + leucine (GMML), which contains final concentrations of $1 \%(\mathrm{v} / \mathrm{v})$ glycerol, $1 \times \mathrm{M} 9$ salts (Sigma-Aldrich), $0.05 \%$ (w/v) NaCl, $1 \mathrm{mM}$ $\mathrm{MgSO}_{4}, 0.1 \mathrm{mM} \mathrm{CaCl}$, and $0.3 \mathrm{mM}$ L-leucine (Sigma-Aldrich). The inclusion of L-leucine is important, as it greatly enhances growth rates. One flask was supplemented with $1 \mathrm{mM}$ $\mathrm{NH}_{2} \mathrm{Y}$ (Sigma-Aldrich) and $0.1 \mathrm{~m} M$ DTT (Mallinckrodt), while the other served as a control. The cultures were grown to saturation, harvested by centrifugation $(6000 \mathrm{~g}, 8 \mathrm{~min})$ and each supernatant was transferred to a Falcon tube. The cell pellets were washed twice by resuspension in $1 \mathrm{~mL}$ of GMML, the cells isolated by centrifugation $(6000 \mathrm{~g}, 8 \mathrm{~min})$, and the supernatant discarded. The washed cell pellets were then resuspended in $0.2 \mathrm{~mL}$ of BugBuster Protein Extraction Reagent (Novagen) and shaken at $37^{\circ} \mathrm{C}$ for $1 \mathrm{~h}$. Cell debris was pelleted by centrifugation $(20,000 \mathrm{~g}, 15 \mathrm{~min})$ and the crude extract filtered using Microcon YM-10 membranes (Millipore). The filtered crude extract was subjected to LCESI-MS analysis using a Zorbax SB-C18 column $(5 \mu \mathrm{m}, 4.6 \times 150 \mathrm{~mm}$, Agilent Technologies) with a linear gradient from 5 to $25 \% \mathrm{MeCN}$ in $0.1 \%$ TFA solution over $8 \mathrm{~min}$ at a flow rate of $0.5 \mathrm{~mL} / \mathrm{min}$. Under these conditions, $\mathrm{NH}_{2} \mathrm{Y}$ elutes at $\approx 13 \% \mathrm{MeCN}$. ESIMS sampling of the eluate was performed under positive ionization mode. Authentic $\mathrm{NH}_{2} \mathrm{Y}$ standard solutions were prepared in water and chromatographed under identical conditions. $\mathrm{NH}_{2} \mathrm{Y}$ from the crude extract was identified on the basis of comparison with the retention time of authentic $\mathrm{NH}_{2} \mathrm{Y}$, as well as by ESI-MS results.

\subsection{Results}

The DH10B E. coli cells grew normally in the presence of $\mathrm{NH}_{2} \mathrm{Y}$, indicating that it is not toxic, though the presence of DTT, included in the medium to maintain a reducing environment, reduced the growth rate by 25 to $35 \%$ (data not shown). Previous studies with DOPA had indicated that inclusion of DTT in the growth medium significantly increased the lifetime of reduced DOPA (Alfonta et al., 2003). Therefore, DTT was maintained in all our experiments despite the reduction in the growth rate. 
The HPLC of crude extracts clearly identified a peak corresponding to $\mathrm{NH}_{2} \mathrm{Y}$, as determined by the retention time and the ESI-MS results, which were identical to those of the authentic standard $\mathrm{NH}_{2} \mathrm{Y}$ solution $\left([\mathrm{M}+\mathrm{H}]^{+} \exp 197,[\mathrm{M}+\mathrm{H}]^{+}{ }_{\text {obs }} 196.9\right)$. The uptake was not determined as a function of time but rather at culture saturation. We were also able to detect $\mathrm{NH}_{2} \mathrm{Y}$ in the supernatant after the cells were harvested by centrifugation, which showed that $\mathrm{NH}_{2} \mathrm{Y}$ remains reduced in the culture throughout the time course of the growth. Together, the results showed that $\mathrm{NH}_{2} \mathrm{Y}$ is not toxic and is taken up into E. coli.

The structure of E. coli Tyr-RS was examined to evaluate whether it would be able to bind $\mathrm{NH}_{2} \mathrm{Y}$ and consequently charge tRNA $\mathrm{Tyr}_{\text {with }}$ wis analogue. Previous reports had demonstrated that E. coli Tyr-RS is unable to adenylate 3-iodo-Tyr (Kiga et al., 2002), suggesting that $\mathrm{NH}_{2} \mathrm{Y}$, which is similar in size, will unlikely be a substrate for Tyr-RS. In support of this hypothesis, the structures of the adenylation domain of E. coli Tyr-RS in the presence of Tyr and adenylated Tyr (Kobayashi et al., 2005) show that residues $\mathrm{Y}_{37}, \mathrm{Q}_{179}$ and $\mathrm{Q}_{195}$, and $\mathrm{D}_{182}$ are within $3.4 \AA$ of the phenol $\mathrm{C}_{3}$ and phenol $\mathrm{C}_{5}$ carbon atoms, respectively, which are ortho to the hydroxyl group at $\mathrm{C}_{4}$. This analysis suggests that $\mathrm{NH}_{2} \mathrm{Y}$ would be unable to bind E. coli Tyr-RS because of unfavorable steric interactions with its 3amino moiety. Although this conclusion needs to be further verified experimentally by isolating and assaying the E. coli Tyr-RS, the foregoing arguments suggest that $\mathrm{NH}_{2} \mathrm{Y}$ meets the final criterion for commencing directed evolution of a specific $\mathrm{NH}_{2} \mathrm{Y}-\mathrm{RS}$.

\section{Directed Evolution of $\mathrm{NH}_{2} \mathrm{Y}-\mathrm{RS}$ in $E$. coli}

In this section, we summarize the general selection process used to isolate $\mathrm{NH}_{2} \mathrm{Y}$-RS. The protocols used to select for an $\mathrm{NH}_{2} \mathrm{Y}$-RS are similar to those previously described in detail and are summarized in Fig. 3.2 (Wang and Schultz, 2004; Xie and Schultz, 2005). The positive selection is performed in DH10B E. coli cells containing the positive selection plasmid, pREP/YC-J17 (Santoro et al., 2002), which carries a tetracycline marker $\left(\mathrm{Tet}^{\mathrm{R}}\right.$ ), and plasmid pBK-JYRS (Wang et al., 2001), which contains the library of RSs and a kanamycin marker $\left(\mathrm{Kn}^{\mathrm{R}}\right)$. The positive selection is based on suppression of an amber stop codon (TAG) at a permissive site in the chloramphenicol acetyl transferase (CAT) gene when DH10B E. coli cells are grown in the presence of chloramphenicol $(\mathrm{Cm}), \mathrm{Kn}$, Tet, $\mathrm{NH}_{2} \mathrm{Y} / \mathrm{DTT}$, and the cognate tRNA on GMML plates. Surviving clones carry RSs that are functional with the host cell's translation machinery and incorporate $\mathrm{NH}_{2} \mathrm{Y}$ or natural amino acids into CAT in response to the amber stop codon. This leads to production of CAT and survival of the clones in the presence of $60 \mu \mathrm{g} / \mathrm{mL} \mathrm{Cm}$. In addition, the positive selection plasmid contains a GFPuv gene under the control of the T7 promoter and a T7 RNA polymerase, which contains amber codons at two permissive sites. Suppression of the amber stop codons generates T7 RNA polymerase, which drives the expression of GFPuv resulting in green fluorescence in the desired clones. Therefore, $\mathrm{Cm}$ resistance and green fluorescence may be monitored to isolate clones that carry the desired RSs (Xie and Schultz, 2005).

After the positive selection, the cells are scraped from the plates and isolated by centrifugation. The vectors pREP/YC-J17 $(\approx 10 \mathrm{~kb})$ and pBK-JYRS $(\approx 3 \mathrm{~kb})$ are isolated using the Qiagen Miniprep Kit and separated on a 1\% agarose gel. Then, pBK-JYRS is extracted using the Qiagen Gel Extraction Kit and transformed into DH10B E. coli cells 
carrying the negative selection plasmid, pLWJ17B3 (Chin et al., 2002; Wang et al., 2003). The negative selection is based on lack of suppression of three amber codons in the barnase gene, which codes for a ribonuclease, when the cells are grown in the absence of $\mathrm{NH}_{2} \mathrm{Y}$ in LB. The RSs that can charge the suppressor mutRNA ${ }_{C U A}$ with a natural amino acid generate barnase, which kills the cells. Thus, this selection removes RSs that are not specific for $\mathrm{NH}_{2} \mathrm{Y}$. The surviving clones carry RSs that do not incorporate any natural amino acids in response to the amber stop codon. The RSs are then examined to determine the fidelity and specificity of $\mathrm{NH}_{2} \mathrm{Y}$ insertion in a model system, as described in the subsequent section.

Four rounds of positive and three rounds of negative selections were required to obtain RSs that were specific for $\mathrm{NH}_{2} \mathrm{Y}$ and did not cross-react with natural amino acids (Seyedsayamdost et al., 2007b). The RS that conferred the highest degree of $\mathrm{Cm}$ resistance $(\approx 110 \mu \mathrm{g} / \mathrm{mL})$ was selected and amplified. The plasmid carrying this RS was designated pBK-NH $\mathrm{N}_{2} \mathrm{Y}$-RS (Seyedsayamdost et al., 2007b). While structural studies have not yet been performed on this RS, DNA sequencing revealed a $\mathrm{Q}_{32}$ instead of the wild-type $\mathrm{Y}_{32}$ (note that this $\mathrm{Y}$ corresponds to $\mathrm{Y}_{37}$ in the $E$. coli Tyr-RS discussed earlier). In the wild-type $M$. jannaschii $\mathrm{RS}$, the phenol oxygen of $\mathrm{Y}_{32}$ is positioned within $3.4 \AA$ of the phenolic $\mathrm{C}$-atom ortho to the hydroxyl group of the Tyr ligand (Kobayashi et al., 2003; Turner et al., 2006; Zhang et al., 2005). In the selected $\mathrm{NH}_{2} \mathrm{Y}-\mathrm{RS}$, this residue is $\mathrm{Q}$, which indicates that the binding pocket has been expanded to allow accommodation for, and perhaps favorable $\mathrm{H}$ bonding interactions with, the $o-\mathrm{NH}_{2}$ moiety of $\mathrm{NH}_{2} \mathrm{Y}$.

\section{Examination of the Fidelity and Specificity of $\mathrm{NH}_{2} \mathrm{Y}$ Incorporation in a Protein Expressed in E. coli}

\subsection{Overview: The Z-domain as a model}

A variety of expression systems for small proteins have been developed by the Schultz lab to assess the fidelity and specificity of unnatural amino acid incorporation. In our case, the efficiency of $\mathrm{NH}_{2} \mathrm{Y}$ incorporation using $\mathrm{pBK}-\mathrm{NH}_{2} \mathrm{Y}$-RS was tested using the C-terminally His-tagged Z-domain of protein A (the Z-domain) (Nilsson et al., 1987; Wang et al., 2003; Zhang et al., 2002). There are several advantages and disadvantages to using small model proteins such as the Z-domain. The advantages are that the Z-domain is small and stable, allowing for robust expression and rapid purification at room temperature. More important, the incorporation of unnatural $\mathrm{Y}$ analogues can be assessed using simple analytical methods, such as MALDI-TOF-MS. Even small modifications, such as addition of an $\mathrm{NH}_{2}$ group $\left(\Delta_{\mathrm{MW}}=15 \mathrm{Da}\right)$ can be easily detected using this method. Further, trypsin digests result in a small set of peptides that can be sequenced using MS methods. In contrast, the Z-domain is a poor surrogate for target enzymes, which are typically larger, less robust, and/or multimeric in nature. Therefore, incorporation of an unnatural amino acid into the Z-domain does not guarantee that it will also occur in the target protein, and thus expression of the latter must be optimized. In addition, the Z-domain is subject to multiple forms of posttranslational modification that complicates MS analysis (Wang et al., 2003). Nevertheless, it provides a rapid test for the efficiency of the evolved RS. 


\subsection{Protocol for incorporation of $\mathrm{NH}_{2} \mathrm{Y}$ into the $\mathrm{Z}$-domain}

The vectors used to incorporate $\mathrm{NH}_{2} \mathrm{Y}$ into the $\mathrm{Z}$-domain were $\mathrm{pBK}-\mathrm{NH}_{2} \mathrm{Y}$-RS and pLEIZ (Wang et al., 2003; Zhang et al., 2002). The latter contains the Z-domain gene with an amber stop codon at residue 7 and is under the control of a $\mathrm{T} 7$ promoter. It also contains the cognate mutRNA $\mathrm{CUA}$ and a $\mathrm{Cm}^{\mathrm{R}}$ marker. The plasmids were cotransformed into BL21(DE3)-competent cells (Invitrogen) using the manufacturer's instructions and plated on LB/agar plates containing $50 \mu \mathrm{g} / \mathrm{mL} \mathrm{Kn}$ and $35 \mu \mathrm{g} / \mathrm{mL} \mathrm{Cm}$. All subsequent cultures were grown in the presence of $\mathrm{Kn}(50 \mu \mathrm{g} / \mathrm{mL})$ and $\mathrm{Cm}(35 \mu \mathrm{g} / \mathrm{mL})$ at $37^{\circ} \mathrm{C}$. A single colony from the plate was inoculated into $5 \mathrm{~mL}$ of $2 \mathrm{YT}$ medium (Becton Dickinson) and grown to saturation $(\approx 13 \mathrm{~h})$. One $\mathrm{mL}$ of this saturated culture was diluted into $25 \mathrm{~mL} 2 \mathrm{YT}$ medium and grown to saturation overnight $(\approx 11 \mathrm{~h})$. Ten $\mathrm{mL}$ of that culture was then diluted into each of $2 \times 1$ L Erlenmeyer flasks containing $250 \mathrm{~mL}$ of GMML. When the $\mathrm{OD}_{600 \mathrm{~nm}}$ reached $0.65(9 \mathrm{~h})$, one of the cultures was supplemented with final concentrations of $1 \mathrm{mM}$ $\mathrm{NH}_{2} \mathrm{Y}$ and $0.1 \mathrm{~m} M$ DTT. The other culture was supplemented only with DTT $(0.1 \mathrm{~m} M)$. Fifteen minutes after addition of $\mathrm{NH}_{2}$ Y/DTT (or DTT), IPTG (Sigma-Aldrich) was added to each culture to a final concentration of $1 \mathrm{mM}$. After $5 \mathrm{~h}$, cells were harvested by centrifugation. The Z-domain produced from these cultures grown in the presence and absence of $\mathrm{NH}_{2} \mathrm{Y}$ was then purified by $\mathrm{Ni}^{2+}$ affinity chromatography (Novagen) under denaturing conditions, per manufacturer's instructions. After purification, the Z-domain was analyzed by SDS-PAGE and MALDI-TOF MS. For MALDI-TOF MS, the Z-domain was exchanged into water by dialysis at $4{ }^{\circ} \mathrm{C}$ using $1-\mathrm{kDa}$ molecular weight cutoff membranes (SpectroPor), and mass spectra were subsequently obtained under positive ionization mode at the Scripps Center for Mass Spectrometry.

\subsection{Results}

The SDS-PAGE analysis of the expression and purification of Z-domain in the presence and absence of $\mathrm{NH}_{2} \mathrm{Y}$ is shown in Fig. 3.3A. The results show that expression of the Z-domain in the presence of $\mathrm{NH}_{2} \mathrm{Y} / \mathrm{DTT}$ in GMML resulted in suppression of the amber stop codon. Typically, $5 \mathrm{mg}$ of Z-domain per liter of culture were obtained after purification. MALDITOF MS analysis of the sample yielded four major peaks (Fig. 3.3B) with MW $=7812$, 7854,7943 , and $7985 \mathrm{Da}$, corresponding to $\mathrm{K}_{7} \mathrm{NH}_{2} \mathrm{Y}$-Z-domain minus the first Met ( $\mathrm{MW}_{\exp }$ $=7813 \mathrm{Da})$, its acetylated form $\left(\mathrm{MW}_{\exp }=7855 \mathrm{Da}\right)$, full-length $\mathrm{K}_{7} \mathrm{NH}_{2} \mathrm{Y}$-Z-domain $\left(\mathrm{MW}_{\exp }=7944 \mathrm{Da}\right)$, and its acetylated form $\left(\mathrm{MW}_{\exp }=7986 \mathrm{Da}\right)$, respectively. As discussed earlier, the Z-domain is subject to posttranslational modifications that result in acetylation of its N-terminus and removal of its first Met residue (Wang et al., 2003). Importantly, $\mathrm{K}_{7} \mathrm{Y}$-Zdomain, which would result from mischarging of mutRNA $\mathrm{CUA}$ with $\mathrm{Y}$ in place of $\mathrm{NH}_{2} \mathrm{Y}$, was not detected in the MALDI-TOF mass spectra. These results indicate that $\mathrm{NH}_{2} \mathrm{Y}$-RS is efficient and specific at suppressing the amber stop codon and inserting $\mathrm{NH}_{2} \mathrm{Y}$. In support of this finding, in the absence of $\mathrm{NH}_{2} \mathrm{Y}$, the amount of $\mathrm{Z}$-domain produced was less than the lower limit of detection $\left(\approx 0.5 \mathrm{mg} / \mathrm{L}\right.$ of culture). Therefore, in the absence of $\mathrm{NH}_{2} \mathrm{Y}$, the amber stop codon is not suppressed, resulting in the lack of expression or low levels of expression of the Z-domain. 


\section{Generation of $Y_{730} \mathrm{NH}_{2} \mathrm{Y}-a 2$ and $\mathrm{Y}_{731} \mathrm{NH}_{2} \mathrm{Y}-a 2$}

\subsection{Overview}

Having selected an $\mathrm{NH}_{2} \mathrm{Y}-\mathrm{RS}$ and demonstrated its ability to efficiently incorporate $\mathrm{NH}_{2} \mathrm{Y}$ into the $\mathrm{Z}$-domain, we next attempted to insert $\mathrm{NH}_{2} \mathrm{Y}$ into the $a$ subunit of RNR. As discussed previously, while the Z-domain allows for rapid assessment of the quality of the evolved RS, the conditions used for optimized expression and suppression of the amber stop codon in the target protein are usually different, as we and other research groups have experienced (Farrell et al., 2005; Neumann et al., 2008). In this section, we describe our initial unsuccessful attempts at incorporating $\mathrm{NH}_{2} \mathrm{Y}$ into $a 2$, as well as our detailed protocol for successful production of $\mathrm{NH}_{2} \mathrm{Y}-\alpha 2 \mathrm{~s}$ in 100-mg quantities with high specificity.

\subsection{Unsuccessful attempts to incorporate $\mathrm{NH}_{2} \mathrm{Y}$ into $a 2$}

Successful incorporation of $\mathrm{NH}_{2} \mathrm{Y}$ into $a 2$ first requires identification of a condition that yields high levels of expression of $a 2$, and then suppression of the amber stop codon under the same growth condition. We first attempted to insert $\mathrm{NH}_{2} \mathrm{Y}$ into $a 2$ using the procedure successful with the Z-domain. pBAD-nrdA (or $n r d A$ with a site-specifically encoded amber codon) carries the gene for $a 2$ under the control of an L-Ara-inducible promoter with an $r r n B$ terminator and the mutRNA $\mathrm{CUA}_{\text {A }}$ gene under the control of a lpp promoter with an $r r n C$ terminator and a $\mathrm{Tet}^{\mathrm{R}}$ marker (Seyedsayamdost et al., 2007b; Zhang et al., 2003). pBK$\mathrm{NH}_{2} \mathrm{Y}$-RS contains the gene for $\mathrm{NH}_{2} \mathrm{Y}$-RS described previously under the control of the constitutive E. coli Gln-RS promoter. Also, pBK- $\mathrm{NH}_{2} \mathrm{Y}-\mathrm{RS}$ and $\mathrm{pBAD}-$ hrdA contain compatible origins of replication, ColE1 and p15A, respectively.

Initially, we examined pBAD- $n r d A$ alone to evaluate expression levels of $\alpha 2$ and $\alpha 2$ containing an amber stop codon (at residue 730) in GMML. In the former case, $\alpha 2$ was overexpressed to $\approx 10 \%$ of total protein; in the latter case, truncated $a 2$ was overexpressed at similar levels. Ensuring expression in the absence of pBK- $\mathrm{NH}_{2} \mathrm{Y}-\mathrm{RS}$ is essential; however, it does not guarantee successful suppression of the amber stop codon.

Next, we examined the expression levels and amber stop codon suppression in cells cotransformed with pBAD-nrdA and pBK- $\mathrm{NH}_{2} \mathrm{Y}$-RS, grown in $\mathrm{NH}_{2} \mathrm{Y} / \mathrm{DTT}$-supplemented GMML. Different conditions of induction and timing of addition of $\mathrm{NH}_{2} \mathrm{Y}$ relative to induction were investigated. In all cases, levels of expression of $a 2$ were low, as determined by SDS-PAGE. Western blot analysis indicated that the levels of $a 2$ in the presence of $\mathrm{NH}_{2} \mathrm{Y}$ were $\approx 2$-fold that of endogenous $a 2$ ( $\alpha 2$ is an essential gene in $E$. coli, data not shown). We attempted growth under anaerobic conditions or aerobic growth in the presence of hydroxyurea. In the former case, the anaerobic class III RNR is operative in E. coli; therefore, wild-type class I $\beta 2$ is not expressed. In the latter case, addition of hydroxyurea leads to reduction of the essential $\mathrm{Y}_{122^{\bullet}}$ in class I $\beta 2$ so that it cannot react with $\mathrm{NH}_{2} \mathrm{Y}-\alpha 2$, if it is in fact expressed. In both cases, the reaction of wild-type $\beta 2$ with $\mathrm{NH}_{2} \mathrm{Y}-\alpha 2$, which could lead to trapping of an $\mathrm{NH}_{2} \mathrm{Y} \bullet$ and subsequent inactivation of $\mathrm{RNR}$, would be minimized. However, neither of the modifications in growth conditions resulted in significant overexpression of $a 2$. 
Continuous technological refinements from the Schultz lab have indicated that mutRNA $A_{C U A}$ is often the limiting factor in production of sufficient levels of a recombinant target protein containing an unnatural amino acid (Ryu and Schultz, 2006). Failure to overexpress $\mathrm{NH}_{2} \mathrm{Y}$ $a 2$, as described previously, might therefore have been due to limiting amounts of mutRNA $_{\mathrm{CUA}}$ inside the cell. To increase the amounts of mutRNA $\mathrm{CUA}_{\mathrm{A}}$, we next attempted expression of $a 2$ with pAC-NH $\mathrm{N}_{2} \mathrm{Y}$-RS, a vector developed by the Schultz lab to overcome this problem. pAC-NH $\mathrm{H}_{2} \mathrm{Y}-\mathrm{RS}$ has six genetic copies of mutRNA $\mathrm{CUA}_{\mathrm{A}}$ under the control of a proK promoter and terminator (Ryu and Schultz, 2006; Seyedsayamdost et al., 2007b). It also carries the $\mathrm{NH}_{2} \mathrm{Y}$-RS gene under the control of a $g \ln S^{\prime}$ promoter, an $r r n B$ terminator, and a $\operatorname{Tet}^{\mathrm{R}}$ marker. While our analysis to understand the low levels of overexpression of $\mathrm{NH}_{2} \mathrm{Y}-a 2$ was in progress, we found, as described subsequently, that pTrc- $n r d A$ and pAC$\mathrm{NH}_{2} \mathrm{Y}$-RS allowed overexpression of $a 2$ and incorporation of $\mathrm{NH}_{2} \mathrm{Y}$; thus, this vector combination became the focus of our efforts. We have not yet reexamined expression $\mathrm{NH}_{2} \mathrm{Y}-a 2$ with $\mathrm{pBAD}-n r d A$ and $\mathrm{pAC}-\mathrm{NH}_{2} \mathrm{Y}-\mathrm{RS}$ and do not entirely understand the basis for the differences in the levels of expression of $a 2$ with different vector combinations.

\subsection{Successful incorporation of $\mathrm{NH}_{2} \mathrm{Y}$ into $a 2$}

Reports of successful overexpression of E. coli nitroreductase using p Trc for production of the target protein (Jackson et al., 2006) prompted us to investigate the pTrc-nrdA/pAC$\mathrm{NH}_{2} \mathrm{Y}$-RS vector combination, simultaneously with efforts described in the preceding section. Thus, $n r d A$ was cloned into the pTrc vector to generate pTrc- $n r d A$. This vector contains $n r d A$ with an amber stop codon under the control of the highly active trp/lac $(\operatorname{trc})$ promoter and an $\mathrm{Amp}^{\mathrm{R}}$ marker (Amann et al., 1988). Its p15a replicon is compatible with the ColE1 origin of pAC-NH $\mathrm{N}_{2} \mathrm{Y}-\mathrm{RS}$. Expression of $\alpha 2$ from pTrc- $n r d A$ in DH10B cells was examined first. Expression and purification yielded $10 \mathrm{mg} a 2$ per gram of wet cell paste, a $2 \times$ to $4 \times$ greater yield than with vector pMJ1-nrdA, which we have routinely used to generate wild-type and mutant $a 2$ s (data not shown) (Mao et al., 1989; Seyedsayamdost et al., 2007b). The activity of $a 2$ produced from pTrc-nrdA was similar to that produced from pMJ1-nrdA ( $\approx 2500 \mathrm{nmol} / \mathrm{min} \mathrm{mg}$ by the spectrophotometric assay) (Ge et al., 2003). Therefore, pTrc- $n r d A$ was suitable for production of $\alpha 2$, allowing expression of $\mathrm{NH}_{2} \mathrm{Y}-\alpha 2$ from pTrc-nrdA and pAC-NH $\mathrm{N}_{2} \mathrm{Y}-\mathrm{RS}$.

\subsection{Protocol for successful expression of $\mathrm{NH}_{2} \mathrm{Y}-a 2 \mathrm{~s}$}

Vectors pTrc-nrdA $A_{730}$ TAG and pTrc- $n r d A_{731}$ TAG were generated from pTrc-nrdA using the site-directed mutagenesis kit (Stratagene), as already described (Seyedsayamdost et al., 2007b). E. coli DH10B cells were transformed with pTrc- $n r d A_{730}$ TAG and pAC-NH $\mathrm{N}_{2} \mathrm{Y}-\mathrm{RS}$ and grown at $37^{\circ} \mathrm{C}$ on LB/agar plates containing Amp $(100 \mu \mathrm{g} / \mathrm{mL})$ and Tet $(25 \mu \mathrm{g} / \mathrm{mL})$ for two days. All liquid culture growths contained Amp $(100 \mu \mathrm{g} / \mathrm{mL})$ and Tet $(25 \mu \mathrm{g} / \mathrm{mL})$ and were carried out in a shaker/incubator at $37^{\circ} \mathrm{C}$ and $200 \mathrm{rpm}$. A single colony from the plate was inoculated into $5 \mathrm{~mL}$ of $2 \mathrm{YT}$ medium and grown to saturation ( $\approx 2$ days). The $5 \mathrm{~mL}$ saturated culture was diluted into $180 \mathrm{~mL}$ of $2 \mathrm{YT}$ medium and grown to saturation $(\approx 1$ day). Twenty five $\mathrm{mL}$ of this culture were then inoculated into each of $6 \times 6 \mathrm{~L}$ Erlenmeyer flasks, each containing $1 \mathrm{~L}$ of GMML medium supplemented with D-biotin $(1 \mu \mathrm{g} / \mathrm{mL}$, Sigma-Aldrich), thiamine ( $1 \mu \mathrm{g} / \mathrm{mL}$, Sigma-Aldrich) and a $1 \times$ heavy metal stock solution. A $1000 \times$ heavy metal stock solution contains the following per liter, as previously described 
(Farrell et al., 2005): $500 \mathrm{mg}$ of $\mathrm{MoNa}_{2} \mathrm{O}_{4} \cdot 2 \mathrm{H}_{2} \mathrm{O}, 250 \mathrm{mg}$ of $\mathrm{CoCl}_{2}, 175 \mathrm{mg}$ of $\mathrm{CuSO}_{4} \cdot 5 \mathrm{H}_{2} \mathrm{O}, 1 \mathrm{~g}$ of $\mathrm{MnSO}_{4} \cdot \mathrm{H}_{2} \mathrm{O}, 8.75 \mathrm{~g}$ of $\mathrm{MgSO}_{4} \cdot 7 \mathrm{H}_{2} \mathrm{O}, 1.25 \mathrm{~g}$ of $\mathrm{ZnSO}_{4} \cdot 7 \mathrm{H}_{2} \mathrm{O}, 1.25 \mathrm{~g}$ of $\mathrm{FeCl}_{2} \bullet 4 \mathrm{H}_{2} \mathrm{O}, 2.5 \mathrm{~g}$ of $\mathrm{CaCl}_{2} \bullet 2 \mathrm{H}_{2} \mathrm{O}$, and $1 \mathrm{~g}$ of $\mathrm{H}_{3} \mathrm{BO}_{3}$ in $1 \mathrm{M} \mathrm{HCl}$. When $\mathrm{OD}_{600} \mathrm{~nm}$ reached 0.6 (12 to $18 \mathrm{~h}), \mathrm{NH}_{2} \mathrm{Y}$ and DTT were added to final concentrations of $1 \mathrm{mM}$ and $0.1 \mathrm{~m} M$, respectively. After $15 \mathrm{~min}$, IPTG was added to a final concentration of $1 \mathrm{~m} M$ and the growth continued for $4.5 \mathrm{~h}$, at which point the cells were harvested by centrifugation, frozen in liquid $\mathrm{N}_{2}$ and stored at $-80{ }^{\circ} \mathrm{C}$. Expression of $\mathrm{Y}_{731} \mathrm{NH}_{2} \mathrm{Y}-a 2$ was carried out in identical fashion using pTrc- $n r d A_{731}$ TAG and pAC-NH ${ }_{2} \mathrm{Y}-\mathrm{RS}$.

\subsection{Results}

Using the foregoing expression procedure, typically $1.5 \mathrm{~g}$ of wet cell paste was obtained per liter of culture. The results for the expression of $\mathrm{Y}_{731} \mathrm{NH}_{2} \mathrm{Y}-\alpha 2$ in DH10B cells doubly transformed with pAC-N $\mathrm{N}_{2} \mathrm{Y}-\mathrm{RS}$ and pTrc-nrdA ${ }_{731} \mathrm{TAG}$ are shown in Fig. 3.4A. In the presence of the IPTG inducer and $\mathrm{NH}_{2} \mathrm{Y} / \mathrm{DTT}$, the amber stop codon is suppressed and $\mathrm{NH}_{2} \mathrm{Y}-\alpha 2$ is overexpressed. In the absence of $\mathrm{NH}_{2} \mathrm{Y}$, overproduction of only truncated $\alpha 2$ is observed. Finally, in the absence of inducer IPTG and $\mathrm{NH}_{2} \mathrm{Y}$, no expression of $a 2$ occurs. A similar profile was obtained for the expression of $\mathrm{Y}_{730} \mathrm{NH}_{2} \mathrm{Y}-\alpha 2$ (Fig. 3.4B).

\subsection{Protocol for purification of $\mathrm{NH}_{2} \mathrm{Y}-a 2 \mathrm{~s}$}

All purification steps were carried out at $4{ }^{\circ} \mathrm{C}$. Typically, $10 \mathrm{~g}$ of wet cell paste (from $\approx 6 \mathrm{~L}$ of growth) were used for purification. Each gram of cell paste was resuspended in $5 \mathrm{~mL}$ of $a 2$ buffer, which consists of $50 \mathrm{~m} M$ Tris, $1 \mathrm{~m} M$ EDTA, pH 7.6, supplemented with $1 \mathrm{~m} M$ PMSF (Sigma-Aldrich) and $5 \mathrm{~m} M$ DTT. PMSF and DTT were added from a $100 \mathrm{~m} M$ stock in isopropanol and a $1 \mathrm{M}$ stock in water, respectively. The cells were lysed using a single passage through a French pressure cell operating at 16,000 psi. After lysis, cell debris was removed by centrifugation $\left(15,000 \mathrm{~g}, 35 \mathrm{~min}, 4^{\circ} \mathrm{C}\right)$. The crude extract was transferred to a $100-\mathrm{mL}$ beaker. DNA was precipitated by dropwise addition of $0.2 \mathrm{vol}$ of $\alpha 2$ buffer containing $1 \mathrm{~m} M$ PMSF, $5 \mathrm{~m} M$ DTT, and $8 \%$ (w/v) streptomycin sulfate (Sigma-Aldrich). The mixture was stirred for an additional $15 \mathrm{~min}$, and the precipitated DNA was removed by centrifugation $\left(15,000 \mathrm{~g}, 35 \mathrm{~min}, 4{ }^{\circ} \mathrm{C}\right)$. The supernatant was transferred to a 100 -mL beaker and $3.9 \mathrm{~g}$ of solid $\left(\mathrm{NH}_{4}\right)_{2} \mathrm{SO}_{4}$ were added per $10 \mathrm{~mL}$ of supernatant over $15 \mathrm{~min}$, which corresponds to $66 \%\left(\mathrm{NH}_{4}\right)_{2} \mathrm{SO}_{4}$ saturation. The mixture was stirred for an additional $30 \mathrm{~min}$ and the precipitated protein was isolated by centrifugation $\left(15,000 \mathrm{~g}, 45 \mathrm{~min}, 4^{\circ} \mathrm{C}\right)$. The supernatant was discarded and the pellet redissolved in 3 to $4 \mathrm{~mL}$ of $a 2$ buffer containing 1 $\mathrm{m} M$ PMSF and $5 \mathrm{~m} M$ DTT. This solution was desalted on a Sephadex G-25 column $(1.5 \mathrm{~cm}$ $\times 25 \mathrm{~cm}, 45 \mathrm{~mL}$, Sigma-Aldrich), which had been equilibrated in $a 2$ buffer. The desalted protein was loaded directly onto a dATP affinity column $(1.5 \mathrm{~cm} \times 4 \mathrm{~cm}, 6 \mathrm{~mL})$, which had been equilibrated in $\alpha 2$ buffer, at $0.5 \mathrm{~mL} / \mathrm{min}$ (Berglund and Eckstein, 1972, 1974). The column was washed with 10 column-volumes of $a 2$ buffer containing $1 \mathrm{mM}$ PMSF and 5 $\mathrm{m} M$ DTT, followed by 2 volumes of $a 2$ buffer containing $5 \mathrm{~m} M$ DTT. Then, $\mathrm{NH}_{2} \mathrm{Y}-a 2$ was eluted in 3 to 4 column-volumes of $a 2$ buffer containing $15 \mathrm{mM} \mathrm{MgSO}_{4}, 10 \mathrm{mM}$ ATP (Sigma-Aldrich), and $10 \mathrm{mM}$ DTT. Subsequently, ATP was removed using a Sephadex G-25 column as described earlier and $\mathrm{NH}_{2} \mathrm{Y}-\alpha 2$ concentrated to $\approx 40 \mu M$ using a Centriprep concentration device (Millipore). Concentrated $\mathrm{NH}_{2} \mathrm{Y}-a 2$ was divided into 0.5 - to 1-mL 
aliquots, flash frozen, and stored at $-80{ }^{\circ} \mathrm{C}$. Typically, 4 to $6 \mathrm{mg}$ of pure $\mathrm{NH}_{2} \mathrm{Y}-a 2$ were obtained per gram of wet cell paste.

\subsection{Assessment of the fidelity and specificity of $\mathrm{NH}_{2} \mathrm{Y}$ insertion into $a 2$}

The analytical methods available for assessing the level of $\mathrm{NH}_{2} \mathrm{Y}$ incorporation into the $\mathrm{Z}$ domain are not feasible with $\alpha 2$. For example, incorporation of $\mathrm{NH}_{2} \mathrm{Y}$ results in a $0.017 \%$ mass increase ( $a_{\mathrm{MW}} \approx 86 \mathrm{kDa}$ ) in $a 2$, as a result of the $o-\mathrm{NH}_{2}$ moiety, which cannot be measured by ESI-MS methods. Further, analysis of trypsin digestion products of $\alpha 2$ is complicated given the large number of resulting peptides. Therefore, assessment of the efficiency of $\mathrm{NH}_{2} \mathrm{Y}$ incorporation into $a 2$ requires alternative methods. In the case of $\mathrm{NH}_{2} \mathrm{Y}$, two such methods have been considered. The first involves incorporation of $\left[{ }^{14} \mathrm{C}\right]-\mathrm{NH}_{2} \mathrm{Y}$ or $\left[{ }^{3} \mathrm{H}\right]-\mathrm{NH}_{2} \mathrm{Y}$ of known specific activity into $a 2$ to determine the amount of $\mathrm{NH}_{2} \mathrm{Y}$ by scintillation counting. A second method involves derivatization of $\mathrm{NH}_{2} \mathrm{Y}$ with a known fluorophore and quantitation of the derivative by fluorescence spectroscopy (Hooker et al., 2004). Both methods are currently being investigated.

The methods we have recently used to address the levels of contaminating wild-type $a 2$ in our $\mathrm{NH}_{2} \mathrm{Y}-a 2$ preparations consist of dCDP production assays in combination with the use of a stoichiometric mechanism-based inhibitor of RNRs, 2'-azido-2'-deoxyadenosine-5'diphosphate ( $\mathrm{N}_{3} \mathrm{ADP}$ ) (Thelander et al., 1976). $\mathrm{NH}_{2} \mathrm{Y}-a 2$ s were assayed for dCDP formation using the discontinuous radioactive assay with thioredoxin (TR), thioredoxin reductase (TRR), and NADPH as reductants. Our previous studies have shown that an activity $\left\{1 / 10^{4}\right\}$ that of wild-type RNR is the lower limit of detection by this assay (Seyedsayamdost and Stubbe, 2006; Yee et al., 2003b). Observation of nucleotide reduction activity would suggest that either our $\mathrm{NH}_{2} \mathrm{Y}-\alpha 2$ preparations have a high level of $\mathrm{Y}$ incorporated at residues 730 (or 731) or that the $\mathrm{NH}_{2} \mathrm{Y}-a 2 \mathrm{~s}$ are inherently active in nucleotide reduction.

To distinguish between the two options, $\mathrm{N}_{3} \mathrm{ADP}$ was used to quantitate the amount of wildtype $a 2$. Previous studies have revealed that wild-type RNR is inactivated with 1 equivalent of $\mathrm{N}_{3} \mathrm{NDP}$, resulting in loss of $50 \% \mathrm{Y}_{122^{\bullet}}$ (between $20 \mathrm{~s}$ and $2 \mathrm{~min}$ ) and formation of 1 equivalent of a new substrate-derived nitrogen-centered radical (N•, Fig. 3.5A) (Fritscher $e t$ al., 2005; Salowe et al., 1993; Sjöberg et al., 1983; van der Donk et al., 1995). The amount of $\mathrm{N} \bullet$ is directly proportional to the amount of active RNR in solution (Ekberg et al., 1998). Importantly, the EPR spectral features of $\mathrm{N} \bullet, \mathrm{Y}_{122^{\bullet}}$, and $\mathrm{NH}_{2} \mathrm{Y} \bullet$ do not overlap in the lowfield region, thereby allowing spectral deconvolution and quantitation of these three species (Fig. 3.5B).

\subsection{Protocol for measurement of catalytic activities of $\mathrm{NH}_{2} \mathrm{Y}-a 2 \mathrm{~s}$}

The assay contained in a final volume of $230 \mu \mathrm{L}: 0.2,1$ or $3 \mu M \mathrm{NH}_{2} \mathrm{Y}-\alpha 2$, a 5-fold molar excess of $\beta 2,1 \mathrm{~m} M\left[5-{ }^{3} \mathrm{H}\right]-\mathrm{CDP}$ (1190 cpm/nmol, Amersham Bioscience), $3 \mathrm{~m} M$ ATP, 30 $\mu M \mathrm{TR}, 0.5 \mu M \mathrm{TRR}$, and $1 \mathrm{~m} M \mathrm{NADPH}$ (Sigma-Aldrich) in assay buffer (50 $\mathrm{m} M$ Hepes, $15 \mathrm{mM} \mathrm{MgSO} 4,1 \mathrm{~m} M$ EDTA, pH 7.6) (Seyedsayamdost et al., 2006b). The purification of TR ( $\approx 40$ units/mg) (Chivers et al., 1997), TRR (1400 units/mg) (Russel and Model, 1985), and $\beta 2(7200 \mathrm{nmol} / \mathrm{min} \mathrm{mg})$ (Salowe and Stubbe, 1986) have been described. For each 
reaction, nucleotides, TR, TRR, and $\alpha 2$ were incubated at $25^{\circ} \mathrm{C}$ for 1.5 to $2 \mathrm{~min}$. The reaction was then initiated by addition of wild-type $\beta 2$ and NADPH. At defined time points, usually $0,1,2,3$, and $5 \mathrm{~min}, 40 \mu \mathrm{L}$ were withdrawn and quenched in $25 \mu \mathrm{L}$ of $2 \%(\mathrm{v} / \mathrm{v})$ perchloric acid (Sigma-Aldrich). After the time course, the reactions were neutralized with $20 \mu \mathrm{L}$ of $0.5 \mathrm{M} \mathrm{KOH}$ (Fisher Bioscience). The samples were incubated at $-20^{\circ} \mathrm{C}$ overnight to ensure complete precipitation of potassium perchlorate. The samples were then thawed on ice and spun down for $3 \mathrm{~min}$ at 21,000 $\mathrm{g}$ in a tabletop centrifuge. Each supernatant was transferred to a 1.5 -mL screw-top microfuge tube, to which was added 14 units of calfintestine alkaline phosphatase (Roche), $120 \mathrm{nmol}$ of carrier deoxycytidine (Sigma-Aldrich), and final concentrations of $75 \mathrm{~m} M$ Tris and $0.15 \mathrm{~m} M$ EDTA (pH 8.5). The samples were incubated at $37{ }^{\circ} \mathrm{C}$ for $2 \mathrm{~h}$ and the amount $\left[{ }^{3} \mathrm{H}\right]-\mathrm{dC}$ in each sample was quantitated using the method of Steeper and Steuart (1970).

\subsection{Protocol for use of the mechanism-based RNR inhibitor, $N_{3} A D P$}

The preparation of $\mathrm{N}_{3} \mathrm{ADP}$ and other $\mathrm{N}_{3} \mathrm{NDPs}$, which may be used in this assay, has already been described (Hobbs and Eckstein, 1977; Robins et al., 1992; Salowe et al., 1987). The procedure for prereduction of $\mathrm{NH}_{2} \mathrm{Y}-\alpha 2 \mathrm{~s}$ has also been reported (Seyedsayamdost et al., 2007b). Prereduced $\mathrm{NH}_{2} \mathrm{Y}-a 2$ (or wild-type $a 2$ ) and dGTP (Sigma-Aldrich) were mixed

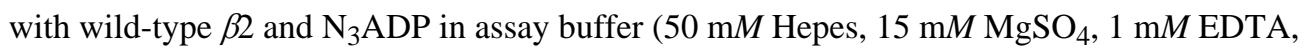
$\mathrm{pH}$ 7.6) to yield final concentrations of $20 \mu M, 1 \mathrm{~m} M, 20 \mu M$, and $250 \mu M$, respectively. The mixture was transferred to an EPR tube (Wilmad) and the reaction quenched after $20 \mathrm{~s}$ by inserting the tube into liquid $\mathrm{N}_{2}$. EPR spectra were subsequently recorded at $77 \mathrm{~K}$ on a Bruker ESP-300 X-band spectrometer equipped with a quartz finger dewar filled with liquid $\mathrm{N}_{2}$. The EPR parameters were as follows: microwave frequency $=9.34 \mathrm{GHz}$, power $=30$ $\mu \mathrm{W}$, modulation amplitude $=1.5 \mathrm{G}$, modulation frequency $=100 \mathrm{kHz}$, time constant $=5.12$ $\mathrm{ms}$, and scan time $=41.9 \mathrm{~s}$. Analysis of the resulting spectra was carried out using an inhouse written program in Excel and WinEPR (Bruker). These programs allow for accurate subtraction of the different spectral components in the reaction. In the experiments, deconvolution of the three signals observed $\left(\mathrm{Y}_{122^{\bullet}}, \mathrm{NH}_{2} \mathrm{Y} \bullet\right.$, and $\left.\mathrm{N}^{\bullet}\right)$ was performed by first subtracting the $\mathrm{N} \bullet$ spectrum, which is well established. Then, the well-characterized spectrum of unreacted $\mathrm{Y}_{122^{\bullet}}$ was subtracted, yielding the $\mathrm{NH}_{2} \mathrm{Y} \bullet-a 2$ spectrum. The ratio of the three signals was determined by comparing the double integral intensity of each trace. The EPR spin quantitation was carried out using a $\mathrm{Cu}^{\mathrm{II}}$ standard as has been described elsewhere (Palmer, 1967).

\subsection{Results of activity and $N_{3}$ ADP assays}

The activity assays for wild-type $a 2, \mathrm{Y}_{730} \mathrm{NH}_{2} \mathrm{Y}-\alpha 2$ and $\mathrm{Y}_{731} \mathrm{NH}_{2} \mathrm{Y}-a 2$ are summarized in Table 3.1. The results show that the $\mathrm{NH}_{2} \mathrm{Y}-a 2$ variants retain significant nucleotide reduction activity. This activity may be inherent to $\mathrm{NH}_{2} \mathrm{Y}-a 2 \mathrm{~s}$ or may be attributed to wildtype endogenous $a 2$ or wild-type $a 2$ generated by mischarging of mutRNA $\mathrm{CUA}_{\mathrm{A}}$ with $\mathrm{Y}$ rather than $\mathrm{NH}_{2} \mathrm{Y}$. To distinguish among the three options, $\mathrm{N}_{3} \mathrm{ADP}$ assays were carried out. As mentioned earlier, detailed characterization of wild-type $\alpha 2$ with $\mathrm{N}_{3}$ NDPs by several groups has shown that after 20 to $120 \mathrm{~s}, 50$ to $60 \%$ of the wild-type $a 2$ population will generate the well-characterized $\mathrm{N} \bullet$ spectrum. Therefore, if the residual activity observed is 
due to wild-type $a 2$, we would expect that $3.5 \%$ and $2 \%$ of $a 2$ would contain the $\mathrm{N} \cdot$ with $\mathrm{Y}_{731} \mathrm{NH}_{2} \mathrm{Y}-a 2$ and $\mathrm{Y}_{730} \mathrm{NH}_{2} \mathrm{Y}-a 2$, respectively.

The $\mathrm{N}_{3} \mathrm{ADP}$ assays on $\mathrm{NH}_{2} \mathrm{Y}-\alpha$ 2s showed that for both $\mathrm{Y}_{730} \mathrm{NH}_{2} \mathrm{Y}-\alpha 2$ and $\mathrm{Y}_{731} \mathrm{NH}_{2} \mathrm{Y}-a 2$, $15 \%$ of the initial $\mathrm{Y}_{122^{\bullet}}$ generates a $\mathrm{N} \bullet$ (Table 3.1). This amount is significantly greater than the amount of $\mathrm{N} \bullet$ expected, if its formation was due to wild-type $a 2$. Therefore, the results indicate that the $\mathrm{NH}_{2} \mathrm{Y}-a 2 \mathrm{~s}$ are inherently active and capable of generating a $\mathrm{C}_{439^{\circ}}$, which gives rise to the $\mathrm{N} \bullet$. Further, they show that wild-type $a 2$ levels in $\mathrm{NH}_{2} \mathrm{Y}-a 2$ preparations are low, indicating specific and efficient incorporation of $\mathrm{NH}_{2} \mathrm{Y}$. As we have discussed before, the activity of $\mathrm{NH}_{2} \mathrm{Y}-a 2 \mathrm{~s}$ has major implications regarding the mechanism of radical propagation at residue $\mathrm{Y}_{730}$ (Seyedsayamdost et al., 2007b). One problem with the $\mathrm{N}_{3} \mathrm{ADP}$ assay is that $\mathrm{NH}_{2} \mathrm{Y} \bullet-a 2$ is unstable on the time scale of the experiment resulting in loss of $20 \%$ of total spin. The other two radicals in this reaction, $\mathrm{Y}_{122}{ }^{\bullet}$ and $\mathrm{N} \bullet$, have been shown to be stable over $20 \mathrm{~s}$. Thus, the $\mathrm{NH}_{2} \mathrm{Y} \bullet$ may partition between two pathways (Fig. 3.6). It may give rise to a $\mathrm{C}_{439^{\circ}}$, which generates a $\mathrm{N} \bullet$, or it may be reduced by components of the assay buffer. The latter pathway results in loss of spin.

Together, results from RNR activity and $\mathrm{N}_{3} \mathrm{ADP}$ assays suggest that $\mathrm{NH}_{2} \mathrm{Y}$ incorporation into $a 2$ was efficient and specific; however, an accurate determination of the level of $\mathrm{NH}_{2} \mathrm{Y}$ insertion will require one of the quantitative methods discussed in section 6.7.

\section{Characterization of $\mathrm{NH}_{2} \mathrm{Y}-a 2 \mathrm{~s}$}

\subsection{Overview}

For $\mathrm{NH}_{2} \mathrm{Y}$ to serve as a useful probe for enzymes that employ $\mathrm{Y} \bullet \mathrm{s}$ or modified $\mathrm{Y} \bullet \mathrm{s}$ in catalysis, its spectroscopic properties must be known. In this section, we describe the procedures we have used to characterize the EPR and UV-vis properties of $\mathrm{NH}_{2} \mathrm{Y} \bullet-\alpha 2$. We also present the protocols for determining the rate constant for $\mathrm{NH}_{2} \mathrm{Y} \bullet-\alpha 2$ formation using stopped flow (SF) UV-vis and rapid freeze-quench (RFQ) EPR spectroscopic methods.

\subsection{Protocol for determining the EPR and UV-vis properties of $\mathrm{NH}_{2} \mathrm{Y} \cdot-a 2 \mathrm{~s}$}

To determine the EPR spectrum of $\mathrm{NH}_{2} \mathrm{Y} \bullet-a 2$, prereduced $\mathrm{NH}_{2} \mathrm{Y}-a 2$ and ATP were mixed with wild-type $\beta 2$ and CDP in assay buffer to give final concentrations of 20 to $24 \mu M, 3$ $\mathrm{m} M$, and 20 to $24 \mu M, 1 \mathrm{~m} M$, respectively. The mixture was transferred to an EPR tube and quenched at defined time points by freezing in liquid $\mathrm{N}_{2}$. The EPR spectra were recorded at $77 \mathrm{~K}$ and analyzed as described in section 6.8 .

To determine the absorption features of $\mathrm{NH}_{2} \mathrm{Y}_{730^{\bullet}}$ and $\mathrm{NH}_{2} \mathrm{Y}_{731^{\circ}}$, SF UV-vis kinetics were carried out on an Applied Photophysics DX 17MV instrument equipped with the Pro-Data upgrade using PMT and diode array detection at $25{ }^{\circ} \mathrm{C}$. Prereduced $\mathrm{Y}_{730} \mathrm{NH}_{2} \mathrm{Y}-\alpha 2$ (or $\mathrm{Y}_{731} \mathrm{NH}_{2} \mathrm{Y}-\alpha 2$ ) and ATP in one syringe were rapidly mixed in a 1:1 ratio with wild-type $\beta 2$ and CDP from a second syringe to yield final concentrations of 8 to $10 \mu M, 3 \mathrm{mM}$, and 8 to $10 \mu M, 1 \mathrm{~m} M$, respectively, in assay buffer. Initially, data was collected with a PDA.1 diode array detector by recording a spectrum between 300 and $700 \mathrm{~nm}$ every $100 \mathrm{~ms}$ after mixing. After identifying the spectral region at which $\mathrm{NH}_{2} \mathrm{Y} \bullet$ absorbs, the reaction was repeated using PMT detection to obtain a more accurate absorption profile of $\mathrm{NH}_{2} \mathrm{Y} \bullet-\alpha 2$. Two to four 
traces were recorded on a 1.5 to $2 \mathrm{~s}$ time scale and averaged between 305 and $365 \mathrm{~nm}$ in 5$\mathrm{nm}$ intervals. The absorption change was corrected for the absorption of $\mathrm{Y}_{122^{\bullet}}$ in this region, given its well-characterized $\varepsilon$ at these $\lambda \mathrm{s}$, (Bollinger et al., 1995; Gräslund et al., 1985; Nyholm et al., 1993) and then plotted against $\lambda$. Calculation of the $\varepsilon$ for $\mathrm{Y}_{730} \mathrm{NH}_{2} \mathrm{Y} \bullet-a 2$ $\left(10,500 \mathrm{M}^{-1} \mathrm{~cm}^{-1}\right)$ and $\mathrm{Y}_{731} \mathrm{NH}_{2} \mathrm{Y} \bullet-\alpha 2\left(11,000 \mathrm{M}^{-1} \mathrm{~cm}^{-1}\right)$ was performed using the $\varepsilon$ of $\mathrm{Y}_{122^{\bullet}}\left(\varepsilon_{410 \mathrm{~nm}}=3,700 \mathrm{M}^{-1} \mathrm{~cm}^{-1}\right)$ (Bollinger et al., 1995), assuming that consumption of each mole of $\mathrm{Y}_{122} \bullet$ leads to formation of 1 mole of $\mathrm{NH}_{2} \mathrm{Y} \bullet$ in $a 2$. Curve fitting was performed with OriginPro or KaleidaGraph Software.

\subsection{Results}

To monitor changes in the concentration of $\mathrm{NH}_{2} \mathrm{Y} \bullet$, its UV-vis and EPR spectral features must first be determined. These properties have facilitated our studies on $\mathrm{NH}_{2} \mathrm{Y}-a 2 \mathrm{~s}$ and will aid other research groups that intend to use $\mathrm{NH}_{2} \mathrm{Y}$ as a probe. The reaction of $\mathrm{NH}_{2} \mathrm{Y}$ $\alpha 2 / \beta 2$ with CDP/ATP, monitored by EPR spectroscopy, is shown in Fig. 3.7. The observed spectrum (Fig. 3.7A, black trace) is a mixture of two species: $\mathrm{Y}_{122} \bullet$ and $\mathrm{NH}_{2} \mathrm{Y} \bullet$. The distinct low-field features of $\mathrm{Y}_{122^{\bullet}}$ were used to subtract its contribution from the observed spectrum to reveal the red trace in Fig. 3.7A, the spectrum of $\mathrm{NH}_{2} \mathrm{Y}_{731^{\circ}}$. It consists of a fairly isotropic signal with a $g$ value of 2.0043 as expected for an organic radical. In the absence of substrate and effector, only the $\mathrm{Y}_{122} \bullet$ is observed (Fig. 3.7B). This is an important control indicating pathway-dependent formation of $\mathrm{NH}_{2} \mathrm{Y} \bullet$ only when substrate and effector are bound to the $\mathrm{NH}_{2} \mathrm{Y}-\alpha 2 / \beta 2$ complex. Interestingly, the spectra of $\mathrm{NH}_{2} \mathrm{Y}_{730^{\bullet}}$ and $\mathrm{NH}_{2} \mathrm{Y}_{731} \bullet$ are similar but distinct, perhaps reflecting differences in the conformation(s) and/or environment around residue 730 vs. 731 (Fig. 3.7C).

Next, we wished to characterize the UV-vis features of $\mathrm{NH}_{2} \mathrm{Y} \bullet$. We hypothesized that its absorption profile would be similar to that of DOPA •(Craw et al., 1984), given the structural similarity between the two species. SF diode array spectroscopy clearly showed changes in the region between 310 and $365 \mathrm{~nm}$ (data not shown). The extinction coefficients associated with $\mathrm{Y}_{122}$ between 310 and $365 \mathrm{~nm}$ are known and small $(\varepsilon \approx 500$ to 1900 $\mathrm{M}^{-1} \mathrm{~cm}^{-1}$ ) (Bollinger et al., 1995; Gräslund et al., 1985; Nyholm et al., 1993) and can be used in spectral deconvolution. To determine the features of $\mathrm{NH}_{2} \mathrm{Y} \bullet$ more accurately, $\mathrm{SF}$ $\mathrm{UV}$-vis was carried out using PMT detection. The absorbance change at $1.5 \mathrm{~s}$ at each $\lambda$, corrected for the absorption by the $\mathrm{Y}_{122^{\bullet}}$, was plotted against the $\lambda$. The results are shown in Fig. 3.8A and indicate that $\mathrm{NH}_{2} \mathrm{Y}_{730^{\bullet}}$ and $\mathrm{NH}_{2} \mathrm{Y}_{731^{\bullet}}$ have similar absorption profiles, which resemble the profile of DOPA $\bullet$ (Craw et al., 1984). The UV-vis spectrum of $\mathrm{NH}_{2} \mathrm{Y}_{730^{\bullet}}$ consists of a broad feature with a $\lambda_{\max }$ at $325 \mathrm{~nm}\left(\varepsilon \approx 10,500 \mathrm{M}^{-1} \mathrm{~cm}^{-1}\right)$. The $\mathrm{NH}_{2} \mathrm{Y}_{731}$ • spectrum exhibits a $\lambda_{\max }$ at $320 \mathrm{~nm}\left(\varepsilon \approx 11,000 \mathrm{M}^{-1} \mathrm{~cm}^{-1}\right)$ and a more defined shoulder at $350 \mathrm{~nm}$.

\subsection{Protocol for determining the kinetics of $\mathrm{NH}_{2} \mathrm{Y} \cdot-a 2$ formation by SF UV-vis spectroscopy}

To determine the kinetics of $\mathrm{Y}_{122^{\bullet}}$ consumption and $\mathrm{NH}_{2} \mathrm{Y} \bullet-a 2$ formation, a reaction identical to the one described previously was carried out. At least six individual traces were averaged at $410 \mathrm{~nm}\left(\lambda_{\max }\right.$ of $\left.\mathrm{Y}_{122^{\circ}}\right)$ and $325 \mathrm{~nm}\left(\lambda_{\max }\right.$ of $\left.\mathrm{NH}_{2} \mathrm{Y}_{730^{\circ}}\right)$ or $320 \mathrm{~nm}\left(\lambda_{\max }\right.$ of $\mathrm{NH}_{2} \mathrm{Y}_{731^{\circ}}$ ). Curve fitting was performed with OriginPro or KaleidaGraph Software. To 
obtain kinetic constants, iterative rounds of fitting and calculation of a residual plot and the $\mathrm{R}^{2}$ correlation value were carried out until both were optimized.

\subsection{Protocol for determining the kinetics of $\mathrm{NH}_{2} \mathrm{Y} \cdot-a 2$ formation by $\mathrm{RFQ}$ EPR spectroscopy}

Rapid freeze-quench EPR samples were prepared using an Update Instruments 1019 Syringe Ram Unit, a Model 715 Syringe Ram Controller, and a quenching bath (which consists of a large outer stainless-steel pot that contains a smaller $\approx 7$-L liquid isopentane bath). The temperature of the liquid isopentane bath was controlled with a Fluke 52 Dual Input Thermometer, equipped with an Anritsu Cu Thermocouple probe for the isopentane bath and the funnel. Stainless-steel packers were purchased from McMaster-Carr and were cut to a length of $40 \mathrm{~cm}$ and deburred at the MIT machine shop. The dead-time of the setup was determined to be $16 \pm 2 \mathrm{~ms}$ with two independent measurements of the myoglobin/ $/ \mathrm{NaN}_{3}$ test reaction according to previously published procedures (Ballou and Palmer, 1974). A packing factor of $0.60 \pm 0.05$ was reproducibly obtained as tested with wild-type $\beta 2$ samples. Routinely, a ram push velocity of 1.25 or $1.6 \mathrm{~cm} / \mathrm{s}$ was used, and the displacement was adjusted to expel $300 \mu \mathrm{L}$ of sample after the reaction.

Operation of the apparatus was similar to the procedures previously described (Ballou and Palmer, 1974; Bollinger et al., 1995). Briefly, the temperature of the isopentane bath was lowered to -135 to $-140{ }^{\circ} \mathrm{C}$ with liquid $\mathrm{N}_{2}$ in the outer bath. One syringe contained $38 \mu \mathrm{M}$ prereduced $\mathrm{Y}_{731} \mathrm{NH}_{2} \mathrm{Y}-\alpha 2$ and $6 \mathrm{~m} M$ ATP in assay buffer and was mixed with $38 \mu M$ wildtype $\beta 2$ and $2 \mathrm{~m} M \mathrm{CDP}$ in assay buffer from a second syringe. When the temperature of the EPR tube-funnel assembly had equilibrated to the bath temperature, the contents of each syringe were mixed rapidly and aged for a predetermined period by traversing the contents through a reaction loop. The sample was then sprayed into the EPR tube-funnel assembly, which was held at a distance of $\leq 1 \mathrm{~cm}$ from the spray nozzle. After the sample was sprayed into the funnel, the assembly was immediately returned to the bath and the crystals allowed to settle for 15 to $30 \mathrm{~s}$. The sample was then packed into the EPR tube using the stainlesssteel packers. After packing, excess isopentane was removed by flicking the EPR tube or by using a Pasteur pipette. The EPR tube was stored in liquid $\mathrm{N}_{2}$ until the EPR spectrum was recorded. Acquisition of EPR spectra was carried out as described in section 6.8. Each time point was collected in duplicates. The quenching times, including the instrument dead time, are indicated in the figure legend.

\subsection{Results of SF UV-vis and RFQ EPR spectroscopic studies}

The SF UV-vis experiments were carried out to monitor the kinetics of $\mathrm{Y}_{122} \bullet$ disappearance and $\mathrm{NH}_{2} \mathrm{Y}_{731} \bullet$ formation. The results are shown in Fig. 3.8B. At $410 \mathrm{~nm}$, biexponential kinetics with rate constants of $17.3 \bullet 0.2$ and $2.3 \pm 0.1 \mathrm{~s}^{-1}$ were observed for loss of $\mathrm{Y}_{122^{\bullet}}$, similar to rate constants obtained for formation of $\mathrm{NH}_{2} \mathrm{Y}_{731} \bullet$ at $320 \mathrm{~nm}\left(21.0 \pm 0.1 \mathrm{~s}^{-1}\right.$ and $\left.3.0 \pm 0.1 \mathrm{~s}^{-1}\right)$. Analogous experiments carried out with $\mathrm{Y}_{730} \mathrm{NH}_{2} \mathrm{Y}-\alpha 2$ showed that disappearance of $Y_{122^{\bullet}}$ occurred biexponentially $\left(12.0 \pm 0.1 \mathrm{~s}^{-1}\right.$ and $\left.2.4 \pm 0.1 \mathrm{~s}^{-1}\right)$, concomitant with formation of $\mathrm{NH}_{2} \mathrm{Y}_{730^{\circ}}\left(13.6 \pm 0.1 \mathrm{~s}^{-1}\right.$ and $2.5 \pm 0.1 \mathrm{~s}^{-1}$, data not shown). A control experiment was carried out in the absence of substrate and effector with $\mathrm{Y}_{731} \mathrm{NH}_{2} \mathrm{Y}-\alpha 2$ (or $\mathrm{Y}_{730} \mathrm{NH}_{2} \mathrm{Y}-\alpha 2$ ) and $\beta 2$. As indicated by EPR experiments, no loss of $\mathrm{Y}_{122^{\bullet}}$ or formation of $\mathrm{NH}_{2} \mathrm{Y} \bullet$ occurred under identical conditions (data not shown). 
The slow and fast rate constants for $\mathrm{NH}_{2} \mathrm{Y} \bullet-a 2$ formation both occur in a fashion that is kinetically competent to be involved in dNDP formation. Thus, studies with the mutants provide the first direct evidence for their involvement in radical propagation. The slow rate constants, also observed in the DOPA- $\beta 2$ experiments, are similar to the steady-state rate constant for RNR turnover. See Seyedsayamdost et al. (2007b) for further discussion of the observed rate constants and amplitudes.

The RFQ-EPR data monitoring formation of $\mathrm{NH}_{2} \mathrm{Y}_{731} \bullet$ is shown in Fig. 3.9. A double exponential fit to the data is not warranted because fewer data points are accessible by this method, relative to SF UV-vis spectroscopy. We have therefore used the SF UV-vis data to fix the rate constant and amplitude of the slow phase in our double exponential fitting procedure of the RFQ-EPR data. The fit then yields the rate constant and amplitude of the fast phase, which are $19.2 \pm 2.4 \mathrm{~s}^{-1}$ and $24 \pm 2 \%$, respectively, in excellent agreement with the dominant kinetic phase in the SF UV-vis experiments. The total amplitude observed in this reaction, $35 \pm 4 \% \mathrm{NH}_{2} \mathrm{Y}_{731} \bullet$ relative to $\left[\mathrm{Y}_{122^{\bullet}}\right.$ ] at $\mathrm{t}=0$, also agrees with the total amplitude for $\mathrm{NH}_{2} \mathrm{Y}_{731} \bullet$ formation from the SF UV-vis studies $\left(35 \pm 1 \% \mathrm{NH}_{2} \mathrm{Y}_{731} \bullet \%\right)$.

\section{Summary}

Studies using the evolved suppressor tRNA/RS pair to incorporate $\mathrm{NH}_{2} \mathrm{Y}$ site-specifically into RNR show the power of this method to study mechanistic issues that are not accessible by any other methods currently available. Site-directed mutagenesis, a universally used method, took decades to evolve into the essential technology it is today. Likewise, incorporation of unnatural amino acids in a similarly robust fashion will require the efforts of many investigators and the sharing of methodological improvements. The radical propagation reaction catalyzed by RNR over $35 \AA$ between two protein subunits is unprecedented. Only with the use of $\mathrm{NH}_{2} \mathrm{Y}$ and other evolved suppressor tRNA/RS pairs (e.g. for fluorotyrosines (Seyedsayamdost et al., 2006a) and 3-nitrotyrosine (Neumann et al., 2008; Yee et al., 2003b)) will the mechanistic details of this remarkable reaction become unveiled.

\section{Acknowledgments}

We are grateful to Prof. Peter G. Schultz and Jianming Xie for sharing their technology in the development of $\mathrm{NH}_{2} \mathrm{Y}-\mathrm{RS}$, Brenda N. Goguen for assistance with Fig. 3.2, and the National Institutes of Health Grant GM29595 for support.

\section{References}

Alfonta L, Zhang Z, Uryu S, Loo JA, Schultz PG. Site-specific incorporation of a redox-active amino acid into proteins. J Am Chem Soc. 2003; 125:14662-14663. [PubMed: 14640614]

Amann E, Ochs B, Abel KJ. Tightly regulated tac promoter vectors useful for the expression of unfused and fused proteins in Escherichia coli. Gene. 1988; 69:301-315. [PubMed: 3069586]

Atkin CL, Thelander L, Reichard P, Lang G. Iron and free radical in ribonucleotide reductase. Exchange of iron and Mossbauer spectroscopy of the protein B2 subunit of the Escherichia coli enzyme. J Biol Chem. 1973; 248:7464-7472. [PubMed: 4355582]

Ballou DP, Palmer G. Practical rapid quenching instrument for the study of reaction mechanisms by electron paramagnetic resonance spectroscopy. Anal Chem. 1974; 46:1248-1253. 
Bennati M, Weber A, Antonic J, Perlstein DL, Robblee J, Stubbe J. Pulsed ELDOR spectroscopy measures the distance between the two tyrosyl radicals in the R2 subunit of the E. coli ribonucleotide reductase. J Am Chem Soc. 2003; 125:14988-14989. [PubMed: 14653724]

Berglund O, Eckstein F. Synthesis of ATP- and dATP-substituted sepharoses and their application in the purification of phage-T4-induced ribonucleotide reductase. Eur J Biochem. 1972; 28:492-496. [PubMed: 5081610]

Berglund O, Eckstein F. ATP- and dATP-substituted agaroses and the purification of ribonucleotide reductases. Methods Enzymol. 1974; 34:253-261. [PubMed: 4615236]

Bollinger JM Jr, Tong WH, Ravi N, Huynh BH, Edmondson DE, Stubbe J. Use of rapid kinetics methods to study the assembly of the diferrictyrosyl radical cofactor of $E$. coli ribonucleotide reductase. Methods Enzymol. 1995; 258:278-303. [PubMed: 8524156]

Chin JW, Martin AB, King DS, Wang L, Schultz PG. Addition of a photocrosslinking amino acid to the genetic code of Escherichia coli. Proc Natl Acad Sci USA. 2002; 99:11020-11024. [PubMed: 12154230]

Chivers PT, Prehoda KE, Volkman BF, Kim BM, Markley JL, Raines RT. Microscopic pKa values of Escherichia coli thioredoxin. Biochemistry. 1997; 36:14985-14991. [PubMed: 9398223]

Climent I, Sjöberg BM, Huang CY. Site-directed mutagenesis and deletion of the carboxyl terminus of Escherichia coli ribonucleotide reductase protein R2. Effects on catalytic activity and subunit interaction. Biochemistry. 1992; 31:4801-4807. [PubMed: 1591241]

Cotton GJ, Ayers B, Xu R, Muir TW. Insertion of a Synthetic Peptide into a Recombinant Protein Framework: A Protein Biosensor. J Am Chem Soc. 1999; 121:1100-1101.

Craw M, Chedekel MR, Truscott TG, Land EJ. The photochemical interaction between the triplet state of 8-methoxypsoralen and the melanin precursor L-3,4 dihydroxyphenylalanine. Photochem Photobiol. 1984; 39:155-159. [PubMed: 6709722]

Cukier RI, Nocera DG. Proton-coupled electron transfer. Annu Rev Phys Chem. 1998; 49:337-369. [PubMed: 9933908]

Dawson PE, Kent SB. Synthesis of native proteins by chemical ligation. Annu Rev Biochem. 2000; 69:923-960. [PubMed: 10966479]

DeFelippis MR, Murthy CP, Broitman F, Weinraub D, Faraggi M, Klapper MH. Electrochemical properties of tyrosine phenoxy and tryptophan indolyl radicals in peptides and amino acid analogs. J Phys Chem. 1991; 95:3416-3419.

Ehrenberg A, Reichard P. Electron spin resonance of the iron-containing protein B2 from ribonucleotide reductase. J Biol Chem. 1972; 247:3485-3488. [PubMed: 4337857]

Ekberg M, Pötsch S, Sandin E, Thunnissen M, Nordlund P, Sahlin M, Sjöberg BM. Preserved catalytic activity in an engineered ribonucleotide reductase $\mathrm{R} 2$ protein with a nonphysiological radical transfer pathway. The importance of hydrogen bond connections between the participating residues. J Biol Chem. 1998; 273:21003-21008. [PubMed: 9694851]

Ekberg M, Sahlin M, Eriksson M, Sjöberg BM. Two conserved tyrosine residues in protein R1 participate in an intermolecular electron transfer in ribonucleotide reductase. J Biol Chem. 1996; 271:20655-20659. [PubMed: 8702814]

Eklund H, Uhlin U, Färnegårdh M, Logan DT, Nordlund P. Structure and function of the radical enzyme ribonucleotide reductase. Prog Biophys Mol Biol. 2001; 77:177-268. [PubMed: 11796141]

Farrell IS, Toroney R, Hazen JL, Mehl RA, Chin JW. Photo-cross-linking interacting proteins with a genetically encoded benzophenone. Nat Methods. 2005; 2:377-384. [PubMed: 16170867]

Fritscher J, Artin E, Wnuk S, Bar G, Robblee JH, Kacprzak S, Kaupp M, Griffin RG, Bennati M, Stubbe J. Structure of the nitrogen-centered radical formed during inactivation of E. coli ribonucleotide reductase by $2^{\prime}$-azido-2'-deoxyuridine- $5^{\prime}$-diphosphate: Trapping of the $3^{\prime}$ ketonucleotide. J Am Chem Soc. 2005; 127:7729-7738. [PubMed: 15913363]

Ge J, Yu G, Ator MA, Stubbe J. Pre-steady-state and steady-state kinetic analysis of E. coli class I ribonucleotide reductase. Biochemistry. 2003; 42:10071-10083. [PubMed: 12939135]

Giriat I, Muir TW. Protein semi-synthesis in living cells. J Am Chem Soc. 2003; 125:7180-7181. [PubMed: 12797783] 
Gräslund A, Sahlin M, Sjöberg BM. The tyrosine free radical in ribonucleotide reductase. Environ Health Perspect. 1985; 64:139-149. [PubMed: 3007085]

Gray HB, Winkler JR. Electron transfer in proteins. Annu Rev Biochem. 1996; 65:537-561. [PubMed: 8811189]

Hobbs JB, Eckstein F. A general method for the synthesis of 2'-azido-2'-deoxy- and 2'-amino-2'deoxyribofuranosyl purines. J Org Chem. 1977; 42:714-719. [PubMed: 839306]

Hooker JM, Kovacs EW, Francis MB. Interior surface modification of bacteriophage MS2. J Am Chem Soc. 2004; 126:3718-3719. [PubMed: 15038717]

Jackson JC, Duffy SP, Hess KR, Mehl RA. Improving nature's enzyme active site with genetically encoded unnatural amino acids. J Am Chem Soc. 2006; 128:11124-11127. [PubMed: 16925430]

Jordan A, Reichard P. Ribonucleotide reductases. Annu Rev Biochem. 1998; 67:71-98. [PubMed: 9759483]

Jovanovic SJS, Tosic M, Marjanovic B, Simic MG. Flavonoids as antioxidants. J Am Chem Soc. 1994; 116:4846-4851.

Kiga D, Sakamoto K, Kodama K, Kigawa T, Matsuda T, Yabuki T, Shirouzu M, Harada Y, Nakayama H, Takio K, Hasegawa Y, Endo Y, et al. An engineered Escherichia coli tyrosyl-tRNA synthetase for site-specific incorporation of an unnatural amino acid into proteins in eukaryotic translation and its application in a wheat germ cell-free system. Proc Natl Acad Sci USA. 2002; 99:97159720. [PubMed: 12097643]

Kobayashi T, Nureki O, Ishitani R, Yaremchuk A, Tukalo M, Cusack S, Sakamoto K, Yokoyama S. Structural basis for orthogonal tRNA specificities of tyrosyl-tRNA synthetases for genetic code expansion. Nat Struct Biol. 2003; 10:425-432. [PubMed: 12754495]

Kobayashi T, Takimura T, Sekine R, Kelly VP, Kamata K, Sakamoto K, Nishimura S, Yokoyama S. Structural snapshots of the KMSKS loop rearrangement for amino acid activation by bacterial tyrosyl-tRNA synthetase. J Mol Biol. 2005; 346:105-117. [PubMed: 15663931]

Kovacs EW, Hooker JM, Romanini DW, Holder PG, Berry KE, Francis MB. Dual-surface-modified bacteriophage MS2 as an ideal scaffold for a viral capsid-based drug delivery system. Bioconjug Chem. 2007; 18:1140-1147. [PubMed: 17602681]

Licht, S.; Stubbe, J. Mechanistic investigations of ribonucleotide reductases. In: Barton, SD.; Nakanishi, K.; Meth-Cohn, O.; Poulter, CD., editors. Comprehensive Natural Products Chemistry. Elsevier Science; New York: 1999. p. 163-203.

Mao SS, Johnston MI, Bollinger JM Jr, Stubbe J. Mechanism-based inhibition of a mutant Escherichia coli ribonucleotide reductase (cysteine-225 $\rightarrow$ serine) by its substrate CDP. Proc Natl Acad Sci USA. 1989; 86:1485-1489. [PubMed: 2493643]

Marcus RA, Sutin N. Electron transfer in chemistry and biology. Biochim Biophys Acta. 1985; 811:265-322.

Mootz HD, Blum ES, Tyszkiewicz AB, Muir TW. Conditional protein splicing: A new tool to control protein structure and function in vitro and in vivo. J Am Chem Soc. 2003; 125:10561-10569. [PubMed: 12940738]

Moser CC, Keske JM, Warncke K, Farid RS, Dutton PL. Nature of biological electron transfer. Nature. 1992; 355:796-802. [PubMed: 1311417]

Muir TW. Semisynthesis of proteins by expressed protein ligation. Annu Rev Biochem. 2003; 72:249289. [PubMed: 12626339]

Muralidharan V, Muir TW. Protein ligation: An enabling technology for the biophysical analysis of proteins. Nat Methods. 2006; 3:429-438. [PubMed: 16721376]

Neumann H, Hazen JL, Weinstein J, Mehl RA, Chin JW. Genetically encoding protein oxidative damage. J Am Chem Soc. 2008; 130:4028-4033. [PubMed: 18321101]

Nilsson B, Moks T, Jansson B, Abrahmsen L, Elmblad A, Holmgren E, Henrichson C, Jones TA, Uhlen M. A synthetic IgG-binding domain based on staphylococcal protein A. Protein Eng. 1987; 1:107-113. [PubMed: 3507693]

Nordlund P, Sjöberg BM, Eklund H. Three-dimensional structure of the free radical protein of ribonucleotide reductase. Nature. 1990; 345:593-598. [PubMed: 2190093] 
Nyholm S, Thelander L, Gräslund A. Reduction and loss of the iron center in the reaction of the small subunit of mouse ribonucleotide reductase with hydroxyurea. Biochemistry. 1993; 32:1156911574. [PubMed: 8218224]

Page CC, Moser CC, Chen X, Dutton PL. Natural engineering principles of electron tunnelling in biological oxidation-reduction. Nature. 1999; 402:47-52. [PubMed: 10573417]

Page CC, Moser CC, Dutton PL. Mechanism for electron transfer within and between proteins. Curr Opin Chem Biol. 2003; 7:551-556. [PubMed: 14580557]

Palmer G. Electron paramagnetic resonance. Methods Enzymol. 1967; 10:595-610.

Pellois JP, Muir TW. Semisynthetic proteins in mechanistic studies: Using chemistry to go where nature can't. Curr Opin Chem Biol. 2006; 10:487-491. [PubMed: 16935551]

Perler FB. Protein splicing mechanisms and applications. IUBMB Life. 2005; 57:469-476. [PubMed: 16081367]

Reece SY, Hodgkiss JM, Stubbe J, Nocera DG. Proton-coupled electron transfer: The mechanistic underpinning for radical transport and catalysis in biology. Philos Trans R Soc Lond B Biol Sci. 2006; 361:1351-1364. [PubMed: 16873123]

Reichard P, Ehrenberg A. Ribonucleotide reductase: A radical enzyme. Science. 1983; 221:514-519. [PubMed: 6306767]

Robins MJ, Hawrelak SD, Hernandez AE, Wnuk SF. Nucleic acid related compounds. LXXXI Efficient general synthesis of purine (amino, azido, and triflate)-sugar nucleosides. Nucleosides Nucleotides. 1992; 11:821-834.

Russel M, Model P. Direct cloning of the trxB gene that encodes thioredoxin reductase. J Bacteriol. 1985; 163:238-242. [PubMed: 2989245]

Ryu Y, Schultz PG. Efficient incorporation of unnatural amino acids into proteins in Escherichia coli. Nat Methods. 2006; 3:263-265. [PubMed: 16554830]

Salowe S, Bollinger JM Jr, Ator M, Stubbe J. Alternative model for mechanism-based inhibition of Escherichia coli ribonucleotide reductase by $2^{\prime}$-azido-2'-deoxyuridine $5^{\prime}$-diphosphate. Biochemistry. 1993; 32:12749-12760. [PubMed: 8251496]

Salowe SP, Ator MA, Stubbe J. Products of the inactivation of ribonucleoside diphosphate reductase from Escherichia coli with 2'-azido-2'-deoxyuridine 5'-diphosphate. Biochemistry. 1987; 26:3408-3416. [PubMed: 3307907]

Salowe SP, Stubbe J. Cloning, overproduction, and purification of the B2 subunit of ribonucleosidediphosphate reductase. J Bacteriol. 1986; 165:363-366. [PubMed: 3511029]

Santoro SW, Wang L, Herberich B, King DS, Schultz PG. An efficient system for the evolution of aminoacyl-tRNA synthetase specificity. Nat Biotechnol. 2002; 20:1044-1048. [PubMed: 12244330]

Seagle RL, Cowgill RW. Fluorescence and the structure of proteins. XXI Fluorescence of aminotyrosyl residues in peptides and helical proteins. Biochim Biophys Acta. 1976; 439:461469. [PubMed: 8119]

Seyedsayamdost MR, Chan CT, Mugnaini V, Stubbe J, Bennati M. PELDOR spectroscopy with DOPA- $\beta 2$ and $\mathrm{NH}_{2} \mathrm{Y}-\alpha 2 \mathrm{~s}$ : Distance measurements between residues involved in the radical propagation pathway of $E$. coli ribonucleotide reductase. J Am Chem Soc. 2007a; 129:1574815749. [PubMed: 18047343]

Seyedsayamdost MR, Reece SY, Nocera DG, Stubbe J. Mono-, di-, tri-, and tetra-substituted fluorotyrosines: New probes for enzymes that use tyrosyl radicals in catalysis. J Am Chem Soc. 2006a; 128:1569-1579. [PubMed: 16448128]

Seyedsayamdost MR, Stubbe J. Site-specific replacement of $\mathrm{Y}_{356}$ with 3,4-dihydroxyphenylalanine in the $\beta 2$ subunit of $E$. coli ribonucleotide reductase. J Am Chem Soc. 2006; 128:2522-2523. [PubMed: 16492021]

Seyedsayamdost MR, Xie J, Chan CT, Schultz PG, Stubbe J. Site-specific insertion of 3-aminotyrosine into subunit $a 2$ of $E$. coli ribonucleotide reductase: Direct evidence for involvement of $\mathrm{Y}_{730}$ and $\mathrm{Y}_{731}$ in radical propagation. J Am Chem Soc. 2007b; 129:15060-15071. [PubMed: 17990884]

Seyedsayamdost MR, Yee CS, Reece SY, Nocera DG, Stubbe J. pH rate profiles of $F_{n} Y_{356}-R 2 s$ ( $n=$ 2, 3, 4) in Escherichia coli ribonucleotide reductase: Evidence that $\mathrm{Y}_{356}$ is a redox-active amino 
acid along the radical propagation pathway. J Am Chem Soc. 2006b; 128:1562-1568. [PubMed: 16448127]

Seyedsayamdost MR, Yee CS, Stubbe J. Site-specific incorporation of fluorotyrosines into the R2 subunit of $E$. coli ribonucleotide reductase by expressed protein ligation. Nat Protoc. 2007c; 2:1225-1235. [PubMed: 17546018]

Sjöberg BM, Gräslund A, Eckstein F. A substrate radical intermediate in the reaction between ribonucleotide reductase from Escherichia coli and 2'-azido-2'-deoxy-nucleoside diphosphates. J Biol Chem. 1983; 258:8060-8067. [PubMed: 6305969]

Sjöberg BM, Reichard P, Gräslund A, Ehrenberg A. The tyrosine free radical in ribonucleotide reductase from Escherichia coli. J Biol Chem. 1978; 253:6863-6865. [PubMed: 211133]

Steeper JR, Steuart CD. A rapid assay for CDP reductase activity in mammalian cell extracts. Anal Biochem. 1970; 34:123-130. [PubMed: 5440901]

Stubbe J. Ribonucleotide reductases: Amazing and confusing. J Biol Chem. 1990; 265:5329-5332. [PubMed: 2180924]

Stubbe J. Ribonucleotide reductases in the twenty-first century. Proc Natl Acad Sci USA. 1998; 95:2723-2724. [PubMed: 9501154]

Stubbe J, Nocera DG, Yee CS, Chang MCY. Radical initiation in the class I ribonucleotide reductase: long-range proton-coupled electron transfer? Chem Rev. 2003; 103:2167-2201. [PubMed: 12797828]

Stubbe J, Riggs-Gelasco P. Harnessing free radicals: Formation and function of the tyrosyl radical in ribonucleotide reductase. Trends Biochem Sci. 1998; 23:438-443. [PubMed: 9852763]

Stubbe J, van der Donk WA. Protein radicals in enzyme catalysis. Chem Rev. 1998; 98:705-762. [PubMed: 11848913]

Thelander L, Larsson B, Hobbs J, Eckstein F. Active site of ribonucleoside diphosphate reductase from Escherichia coli: Inactivation of the enzyme by $2^{\prime}$-substituted ribonucleoside diphosphates. J Biol Chem. 1976; 251:1398-1405. [PubMed: 767333]

Turner JM, Graziano J, Spraggon G, Schultz PG. Structural plasticity of an aminoacyl-tRNA synthetase active site. Proc Natl Acad Sci USA. 2006; 103:6483-6488. [PubMed: 16618920]

Uhlin U, Eklund H. Structure of ribonucleotide reductase protein R1. Nature. 1994; 370:533-539. [PubMed: 8052308]

van der Donk WA, Stubbe J, Gerfen GG, Bellew BF, Griffin RG. EPR investigations of the inactivation of $E$. coli ribonucleotide reductase with $2^{\prime}$-azido-2'-deoxyuridine 5'-diphosphate: Evidence for the involvement of the thiyl radical of C225-R1. J Am Chem Soc. 1995; 117:89098916.

Wang L, Brock A, Herberich B, Schultz PG. Expanding the genetic code of Escherichia coli. Science. 2001; 292:498-500. [PubMed: 11313494]

Wang L, Schultz PG. A general approach for the generation of orthogonal tRNAs. Chem Biol. 2001; 8:883-890. [PubMed: 11564556]

Wang L, Schultz PG. Expanding the genetic code. Angew Chem Int Ed Engl. 2004; 44:34-66. [PubMed: 15599909]

Wang L, Xie J, Schultz PG. Expanding the genetic code. Annu Rev Biophys Biomol Struct. 2006; 35:225-249. [PubMed: 16689635]

Wang L, Zhang Z, Brock A, Schultz PG. Addition of the keto functional group to the genetic code of Escherichia coli. Proc Natl Acad Sci USA. 2003; 100:56-61. [PubMed: 12518054]

Xie J, Schultz PG. An expanding genetic code. Methods. 2005; 36:227-238. [PubMed: 16076448]

Xie J, Schultz PG. A chemical toolkit for proteins: An expanded genetic code. Nat Rev Mol Cell Biol. 2006; 7:775-782. [PubMed: 16926858]

Yee CS, Chang MCY, Ge J, Nocera DG, Stubbe J. 2,3-Difluor-otyrosine at position 356 of ribonucleotide reductase R2: A probe of long-range proton-coupled electron transfer. J Am Chem Soc. 2003a; 125:10506-10507. [PubMed: 12940718]

Yee CS, Seyedsayamdost MR, Chang MCY, Nocera DG, Stubbe J. Generation of the R2 subunit of ribonucleotide reductase by intein chemistry: Insertion of 3-nitrotyrosine at residue 356 as a probe of the radical initiation process. Biochemistry. 2003b; 42:14541-14552. [PubMed: 14661967] 
Zhang Y, Wang L, Schultz PG, Wilson IA. Crystal structures of apo wild-type M. jannaschii tyrosyltRNA synthetase (TyrRS) and an engineered TyrRS specific for O-methyl-L-tyrosine. Protein Sci. 2005; 14:1340-1349. [PubMed: 15840835]

Zhang Z, Smith BA, Wang L, Brock A, Cho C, Schultz PG. A new strategy for the site-specific modification of proteins in vivo. Biochemistry. 2003; 42:6735-6746. [PubMed: 12779328]

Zhang Z, Wang L, Brock A, Schultz PG. The selective incorporation of alkenes into proteins in Escherichia coli. Angew Chem Int Ed Engl. 2002; 41:2840-2842. [PubMed: 12203503] 


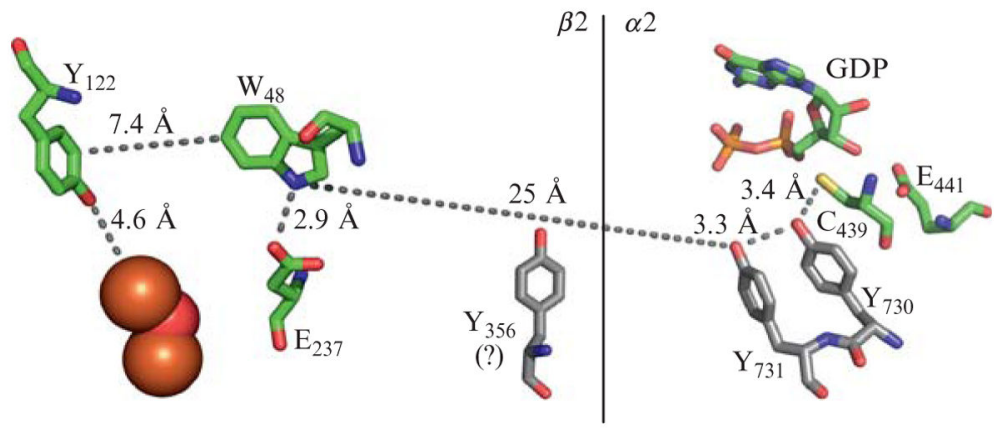

Figure 3.1.

The radical transfer pathway in E. coli RNR. Residues $\mathrm{Y}_{122}, \mathrm{~W}_{48}, \mathrm{E}_{237}$, and $\mathrm{Y}_{356}$ reside in $\beta 2$, while $\mathrm{Y}_{731}, \mathrm{Y}_{730}, \mathrm{C}_{439}$, and $\mathrm{E}_{441}$ reside in $\alpha 2$. Residues in gray have been shown to be redox-active using DOPA- $\beta 2$ and $\mathrm{NH}_{2} \mathrm{Y}-\alpha 2$ s (see text). Note that the position of $\mathrm{Y}_{356}$ is unknown from structural studies. 


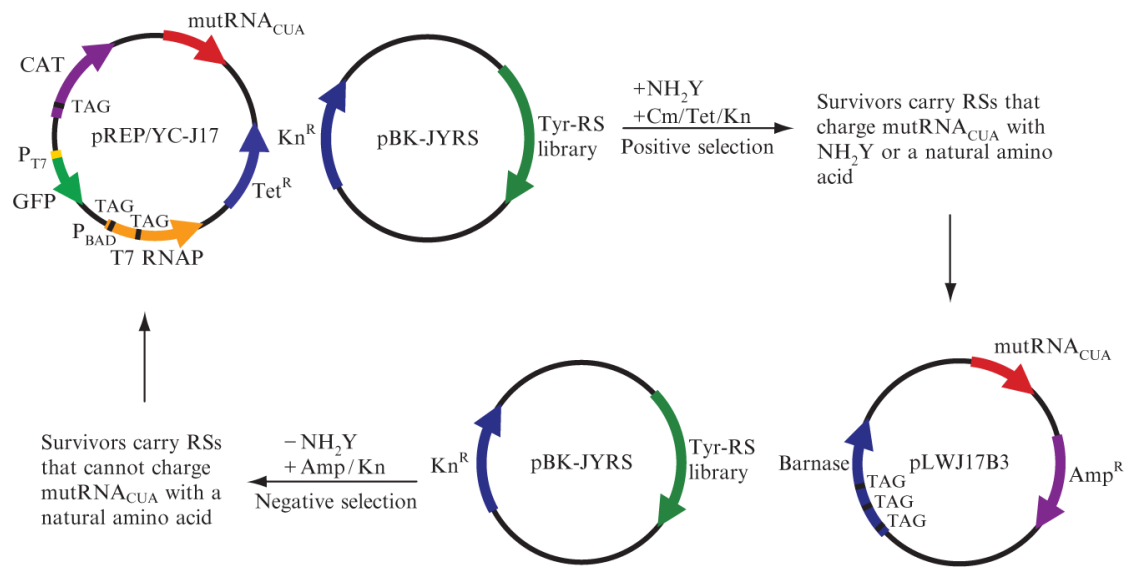

Figure 3.2.

General scheme for selection of $\mathrm{NH}_{2} \mathrm{Y}$-RS. In the positive selection, suppression of a permissive TAG codon in chloramphenicol acetyl transferase (CAT, the $\mathrm{Cm}$ resistance gene) allows synthetases that charge mutRNA $A_{C U A}$ with any amino acid to survive. The positive selection may also be performed by monitoring green fluorescence stemming from GFPuv, which contains a T7 promoter and is expressed when the TAG codons in the T7 RNA polymerase gene are suppressed. The synthetases are then carried through a negative selection cycle in which those that suppress the TAG codons in the barnase gene in the absence of $\mathrm{NH}_{2} \mathrm{Y}$ are eliminated. Therefore, only synthetases that are functional with the host's translation machinery and do not charge mutRNA ${ }_{C U A}$ with a natural amino acid will survive. See text for a description of the features on each plasmid. 
A

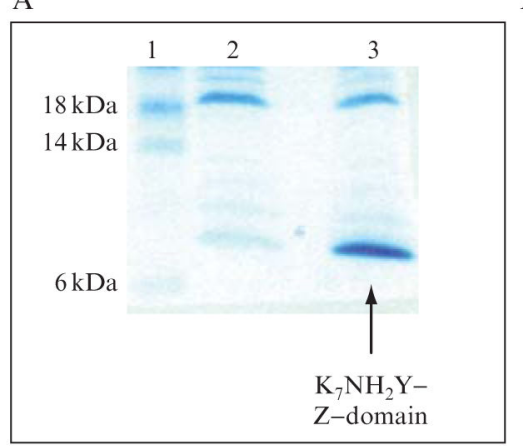

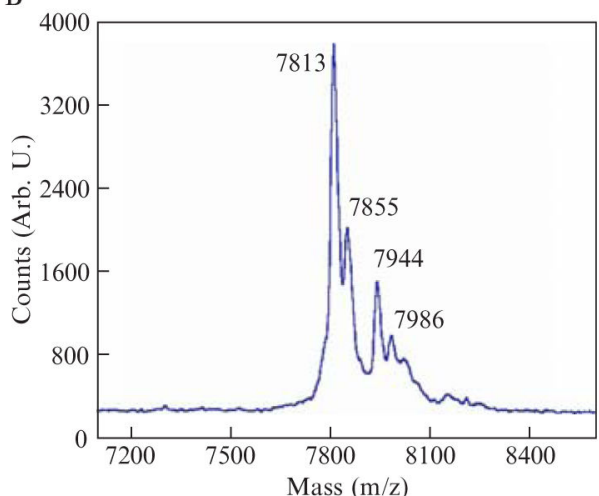

Figure 3.3.

SDS-PAGE and MALDI-TOF MS analysis of $\mathrm{K}_{7} \mathrm{NH}_{2} \mathrm{Y}$-Z-domain. (A) SDS gel of purified $\mathrm{Z}$-domain after expression in the absence (lane 2) or presence (lane 3) of $\mathrm{NH}_{2} \mathrm{Y}$. The arrow designates the band corresponding to $\mathrm{K}_{7} \mathrm{NH}_{2} \mathrm{Y}$-Z-domain. Protein ladder and MWs are shown in lane 1. (B) MALDI-TOF MS of purified $\mathrm{K}_{7} \mathrm{NH}_{2} \mathrm{Y}-\mathrm{Z}$-domain obtained under positive ionization mode. For the four main peaks in the spectrum, $\mathrm{m} / \mathrm{z}[\mathrm{M}+\mathrm{H}]^{+}$are indicated. These correspond to $\mathrm{N}$-terminally cleaved Met form of $\mathrm{K}_{7} \mathrm{NH}_{2} \mathrm{Y}$-Z-domain, [M $+\mathrm{H}]^{+}{ }_{\exp }=7814$; its acetylated form, $[\mathrm{M}+\mathrm{H}]^{+}{ }_{\exp }=7856$; full-length $\mathrm{K}_{7} \mathrm{NH}_{2} \mathrm{Y}-\mathrm{His}-\mathrm{Z}$ domain, $[\mathrm{M}+\mathrm{H}]^{+} \exp =7945$; and its acetylated form, $[\mathrm{M}+\mathrm{H}]^{+} \exp =7987$. 


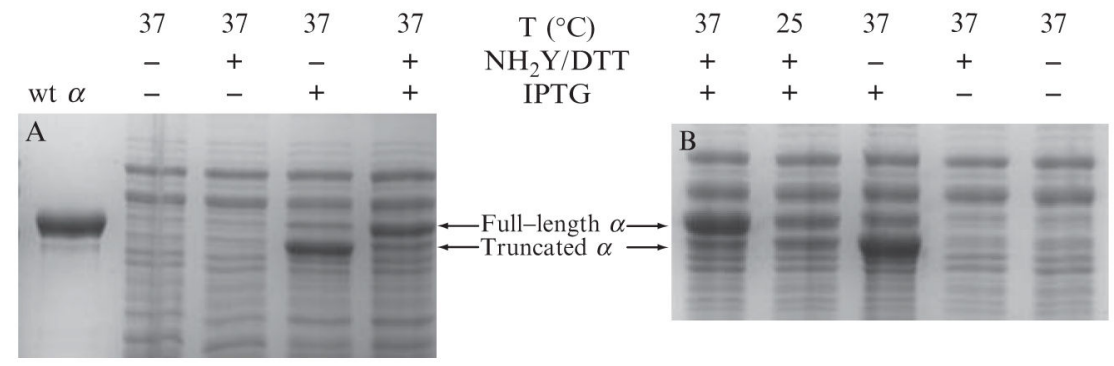

Figure 3.4.

Incorporation of $\mathrm{NH}_{2} \mathrm{Y}$ into $a 2$. Expression of $\mathrm{Y}_{731} \mathrm{NH}_{2} \mathrm{Y}-a 2$ (A) and $\mathrm{Y}_{730} \mathrm{NH}_{2} \mathrm{Y}-a 2$ (B) are shown as a function of IPTG, $\mathrm{NH}_{2} \mathrm{Y} / \mathrm{DTT}$ and temperature. Cells were grown in the presence or absence of IPTG and $\mathrm{NH}_{2} \mathrm{Y} / \mathrm{DTT}$ as indicated and the level of expression assessed by SDS PAGE. The position of protein bands for full-length $a$ and truncated $a$ are denoted by arrows. For both constructs, no expression is observed in the absence of IPTG and expression of truncated $a 2$ is observed in the absence of $\mathrm{NH}_{2} \mathrm{Y}$. Full-length $\mathrm{NH}_{2} \mathrm{Y}-a 2$ is seen only in the presence of IPTG and $\mathrm{NH}_{2}$ Y/DTT. 

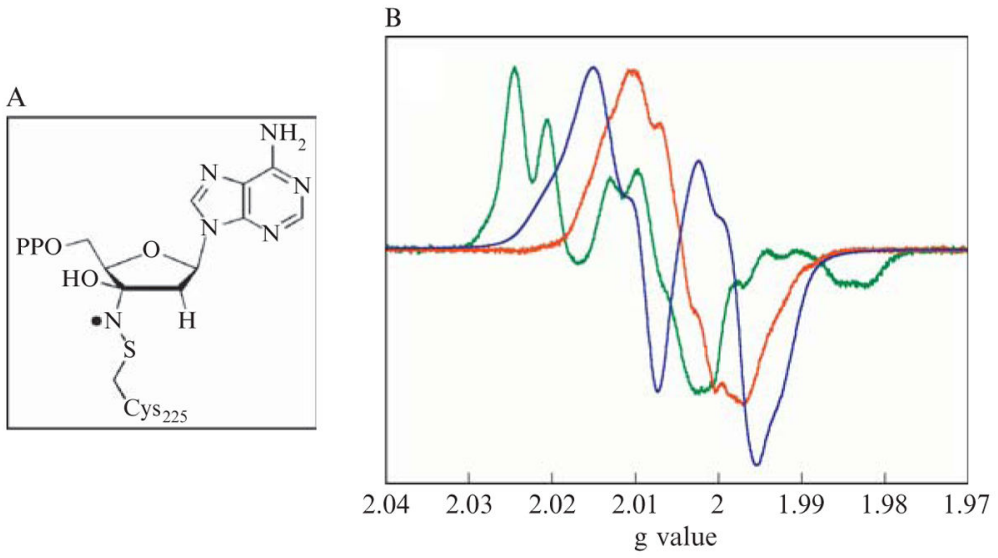

Figure 3.5.

(A) Structure of the active site $\mathrm{N}$-centered radical formed after reaction of RNR with $\mathrm{N}_{3} \mathrm{ADP}$. This radical is formed at the expense of $\mathrm{Y}_{122^{\circ}}$. It is stable on the minute time scale and is abbreviated as $\mathrm{N} \bullet$ in the text. (B) EPR spectra of $\mathrm{N} \bullet$ (green), $\mathrm{Y}_{122} \bullet$ (blue), and $\mathrm{NH}_{2} \mathrm{Y}_{731^{\bullet}}$ (red). The distinct features in the low-field region between $\approx 2.02$ and $\approx 2.03$ were used to perform subtractions and quantitations of the three species in $\mathrm{N}_{3} \mathrm{ADP}$ assays. 

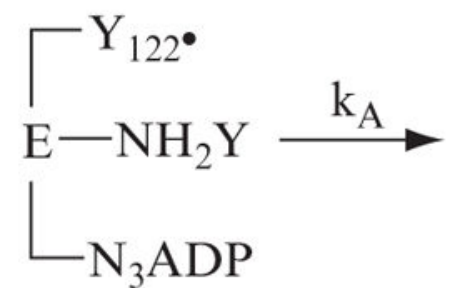
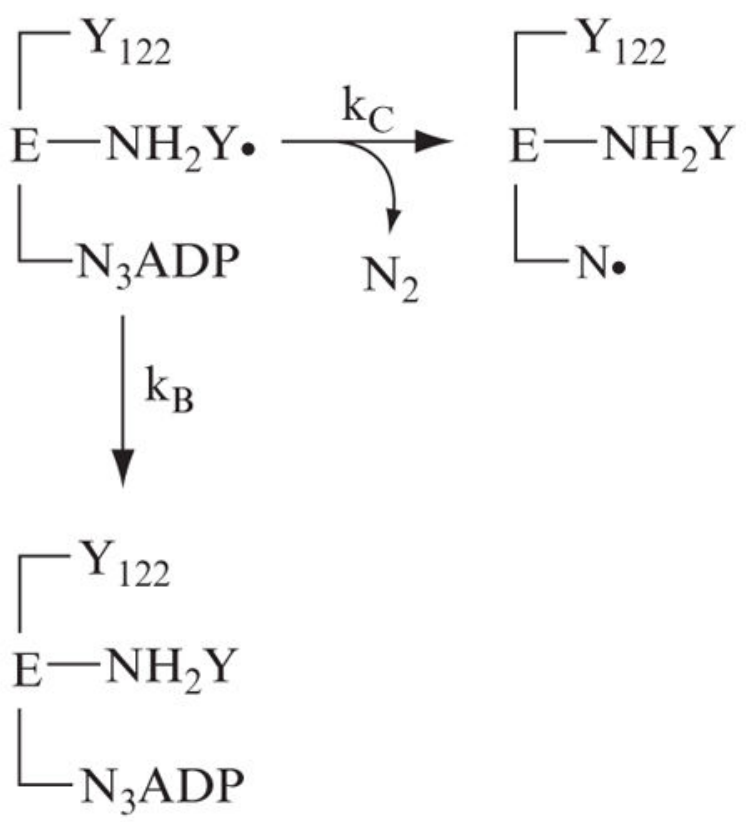

Figure 3.6.

Working model for loss of spin during reaction of $\mathrm{NH}_{2} \mathrm{Y}-a 2 \mathrm{~s}$ with $\mathrm{N}_{3} \mathrm{ADP} / \mathrm{dGTP}$. After radical initiation and $\mathrm{NH}_{2} \mathrm{Y} \bullet$ formation $\left(\mathrm{k}_{\mathrm{A}}\right)$, partitioning occurs between $\mathrm{C}_{439} \bullet$ formation and subsequent $\mathrm{N} \bullet$ formation $\left(\mathrm{k}_{\mathrm{C}}\right)$ or quenching by yet unknown mechanisms $\left(\mathrm{k}_{\mathrm{B}}\right)$. 

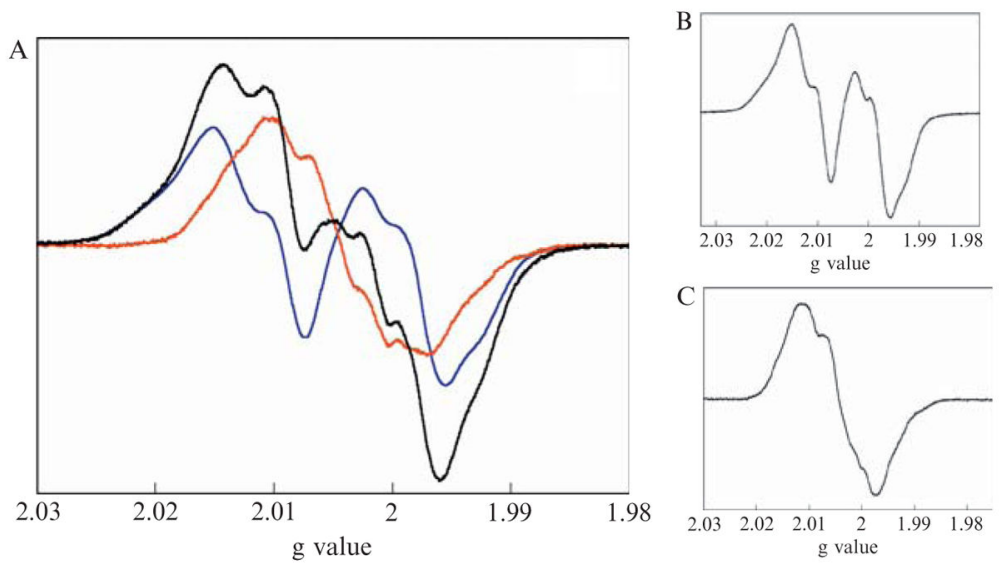

Figure 3.7.

Reaction of $\mathrm{NH}_{2} \mathrm{Y}-a 2 / \mathrm{ATP}$ with wild-type $\beta 2 / \mathrm{CDP}$ monitored by EPR spectroscopy. (A) The reaction components were mixed at $25{ }^{\circ} \mathrm{C}$ to yield final concentrations of $20 \mu \mathrm{M}$ $\mathrm{Y}_{731} \mathrm{NH}_{2} \mathrm{Y}-\alpha 2 / \beta 2$ complex, $1 \mathrm{~m} M$ CDP, and $3 \mathrm{~m} M$ ATP in assay buffer. After $20 \mathrm{~s}$, the reaction was quenched by hand-freezing in liquid $\mathrm{N}_{2}$ and the EPR spectrum recorded at 77 K. Unreacted $\mathrm{Y}_{122^{\bullet}}$ (blue trace, $58 \%$ of total spin) was subtracted from the observed spectrum (black trace) to reveal the spectrum of $\mathrm{NH}_{2} \mathrm{Y}_{731} \bullet$ (red trace, $42 \%$ of total spin). (B) Reaction of $\mathrm{Y}_{731} \mathrm{NH}_{2} \mathrm{Y}-\alpha 2 / \beta 2$ in the absence of CDP/ATP. Only the $\mathrm{Y}_{122^{\bullet}}$ spectrum is observed in this case. (C) Reaction of $\mathrm{Y}_{730} \mathrm{NH}_{2} \mathrm{Y}-\alpha 2$ with $\beta 2$ and CDP/ATP, similar to that described in (A). The subtracted spectrum of $\mathrm{NH}_{2} \mathrm{Y}_{730^{\bullet}}$ is shown. 
A

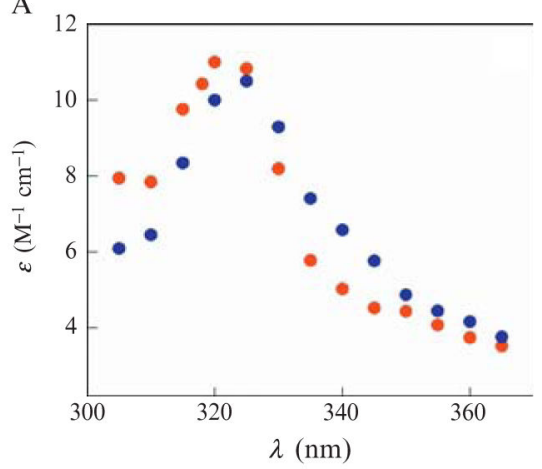

B

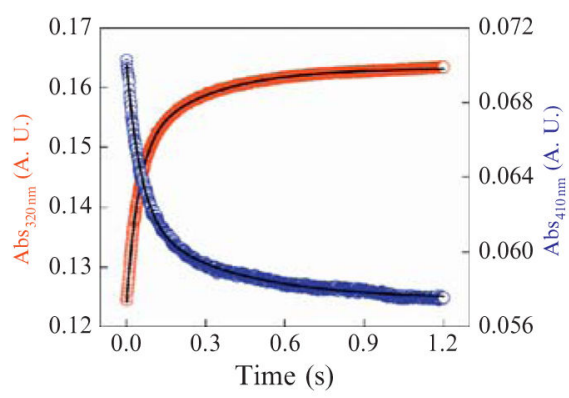

Figure 3.8.

Characterization of $\mathrm{NH}_{2} \mathrm{Y}-a 2$ s by SF UV-vis spectroscopy. (A) Point-by-point reconstruction of the $\mathrm{UV}$-vis spectrum of $\mathrm{NH}_{2} \mathrm{Y}_{730^{\bullet}}$ (blue dots) and $\mathrm{NH}_{2} \mathrm{Y}_{731^{\bullet}}$ (red dots). Prereduced $\mathrm{Y}_{730} \mathrm{NH}_{2} \mathrm{Y}-\alpha 2$ and ATP in one syringe were mixed with wild-type $\beta 2$ and CDP from another syringe, yielding final concentrations of $10 \mu M, 3 \mathrm{~m} M, 10 \mu M$, and $1 \mathrm{~m} M$, respectively. With $\mathrm{Y}_{731} \mathrm{NH}_{2} \mathrm{Y}-\alpha 2$, the reaction was carried out at final concentrations of 9 $\mu M \mathrm{Y}_{731} \mathrm{NH}_{2} \mathrm{Y}-a 2 / \beta 2,1 \mathrm{~m} M \mathrm{CDP}$, and $3 \mathrm{~m} M$ ATP. The absorption change was monitored in 5-nm intervals; at each $\lambda, 2$ to 4 time courses were averaged and corrected for the absorption of $\mathrm{Y}_{122^{\bullet}}$ using previously determined $\varepsilon$ in this spectral range. The corrected $\Delta \mathrm{OD}$ was converted to $\varepsilon$, which was then plotted against $\lambda$. (B) Prereduced $\mathrm{Y}_{731} \mathrm{NH}_{2} \mathrm{Y}-\alpha 2$ and CDP in one syringe were mixed in a 1:1 ratio with $\beta 2$ and ATP from another syringe to yield the same concentrations as in (A). The concentration of $\mathrm{Y}_{122^{\bullet}}$ (blue trace) and $\mathrm{NH}_{2} \mathrm{Y}_{731^{\bullet}}$ (red trace) were monitored at $410 \mathrm{~nm}$ and $320 \mathrm{~nm}$, respectively. A total of 6 traces were averaged at each $\lambda$. See text for kinetic parameters. 
B

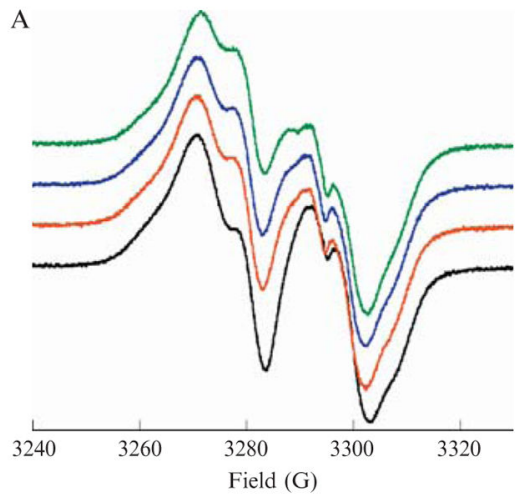

A

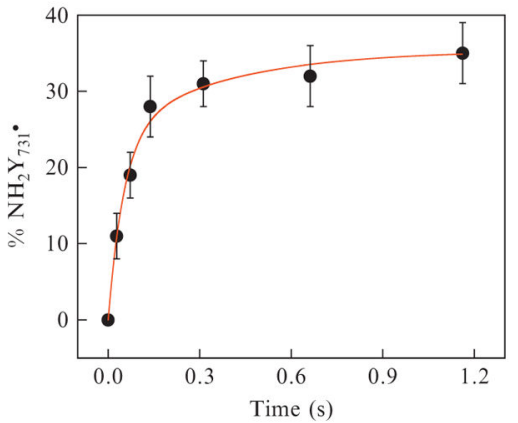

Figure 3.9.

Analysis of $\mathrm{NH}_{2} \mathrm{Y}_{731}$ • formation by rapid-freeze quench EPR spectroscopy. (A) $\mathrm{Y}_{731} \mathrm{NH}_{2} \mathrm{Y}$ $a 2$ and ATP were rapidly mixed with wild-type $\beta 2$ and CDP to yield final concentrations of $19 \mu M \beta 2 / \mathrm{Y}_{731} \mathrm{NH}_{2} \mathrm{Y}-\alpha 2,3 \mathrm{~m} M$ ATP and $1 \mathrm{~m} M$ CDP. The reaction was quenched at various time points by spraying its contents into a liquid isopentane bath maintained at $\approx-140{ }^{\circ} \mathrm{C}$. The EPR spectra were subsequently recorded at $77 \mathrm{~K}$. Shown are the spectra at $0 \mathrm{~ms}$ (black), $72 \mathrm{~ms}$ (red), $312 \mathrm{~ms}$ (blue), and $1.16 \mathrm{~s}$ (green). (B) Kinetic trace obtained after subtracting the $\mathrm{Y}_{122^{\bullet}}$ component from each trace and plotting the percentage of $\mathrm{NH}_{2} \mathrm{Y}_{731^{\bullet}}$ (relative to total spin) versus time. In this double exponential fit, the rate constant and amplitude for the slow phase have been held constant using the values from the SF UV-vis studies. Therefore, the fit yields the parameters for the fast kinetic phase. See text for kinetic parameters. 
Table 3.1

Activities of wild-type $a 2$ and $\mathrm{NH}_{2} \mathrm{Y}-a 2$ s using radioactive product formation and $\mathrm{N}_{3} \mathrm{ADP}$ assays

\begin{tabular}{|lll|}
\hline $\boldsymbol{a}$ 2 variant & Radioactive RNR assay $(\% \mathbf{w t})^{\boldsymbol{a}}$ & $\mathbf{N}_{\mathbf{3}} \mathrm{ADP}$ assay $\left(\boldsymbol{\%} \mathbf{N} \bullet \text { at } 20 \text { s vs. initial } \mathbf{Y}_{\mathbf{1 2 2}}\right)^{\boldsymbol{b}}$ \\
\hline wt $a 2$ & $100^{a}$ & 52 \\
$\mathrm{Y}_{730} \mathrm{NH}_{2} \mathrm{Y}-a 2$ & $4 \pm 0.5$ & $15 \pm 2^{b}$ \\
$\mathrm{Y}_{731} \mathrm{NH}_{2} \mathrm{Y}-\alpha 2$ & $7 \pm 0.5$ & $15 \pm 2^{b}$ \\
\hline
\end{tabular}

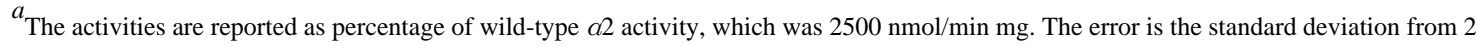
independent measurements.

${ }^{b}$ Note that the amount of $\mathrm{N} \bullet$ is reported relative to $\left[\mathrm{Y}_{122} \cdot\right]$ at $\mathrm{t}=0$; the error is associated with EPR spin quantitation. 